University of New Orleans

ScholarWorks@UNO

$12-2006$

\title{
Putting the Ninth Ward on the Map: Race, Place, and Transformation in Desire, New Orleans
}

Rachel Breunlin

University of New Orleans, rsbreunl@uno.edu

Follow this and additional works at: https://scholarworks.uno.edu/anth_facpubs

Part of the Social and Cultural Anthropology Commons

\section{Recommended Citation}

Breunlin, Rachel, and Helen A. Regis. "Putting The Ninth Ward On The Map: Race, Place, And Transformation In Desire, New Orleans." American Anthropologist 108.4 (December 2006): 744-764.

This Article is brought to you for free and open access by the Department of Anthropology and Sociology at ScholarWorks@UNO. It has been accepted for inclusion in Anthropology Faculty Publications by an authorized administrator of ScholarWorks@UNO.For more information, please contact scholarworks@uno.edu. 


\title{
Putting the Ninth Ward on the Map: Race, Place, and Transformation in Desire, New Orleans
}

\begin{abstract}
In this article, we consider how long-term patterns of resistance to structural violence inform citizens' responses to displacement before and after Katrina. Drawing on Abdou Maliq Simone's (2004) conceptualization of people as infrastructure, we recenter the discussion about the rebuilding of New Orleans around displaced residents, taking the place-making practices of members of a social club as a lens through which to examine the predicament of the city as a whole. Members have been generating alternative ways of thinking about and dwelling together in a restructuring city. Their perspectives are articulated through in-depth interviews, focus groups, and the embodied practices of club members and their followers as they make claims to the city through massive, participatory street processions known as second lines. These distinctive ways of thinking and being in the city-the subaltern mainstream of the second-line tradition-are now being deployed by exiled New Orleanians reconsidering their relationship to home. [Keywords: place, Katrina, urban restructuring, public housing, race]
\end{abstract}

The inner city has been "let go" and forced to reweave its connections with the larger world by making the most of its limited means.

—Abdou Maliq Simone, "People as Infrastructure: Intersecting Fragments in Johannesburg"

$\mathbf{I}$ N THE AFTERMATH OF HURRICANE KATRINA, the mourning of the potential loss of New Orleans is often discussed in relation to the city's distinctive identitya distinctiveness frequently linked to its otherness. Geographers, anthropologists, urban historians, cultural critics, and poets writing about the social and cultural histories of New Orleans have sought to articulate its unique contribution to the U.S. landscape (see, e.g., Campanella 2006a; Campanella and Campanella 1999; Colten 2005; Dent 1982; Domínguez 1986; Johnson 1995; Kelman 2003; Lewis 2003[1976]; Osbey 1997; Pile 2005; Regis 1999; Roach 1996; Saloy 2005; Walker 2005; Ward 2004; ya Salaam 2000). Yet, the contemporary city arguably bears the markings of prototypical U.S. urban policy as well (Eckstein 2006). Urban renewal and slum clearance, discriminatory homeownership programs and segregated public housing, suburbanization and gentrification, along with the rise of gated communities, have all fractured, bulldozed, or reconfigured elements of the 19th-century city that had more in common with the Caribbean archipelago than the U.S. South (see Eckstein and Throgmorton 2003; Gottdiener 1985; Holston 1999;
Jackson 1985; Low 1999, 2003; Rutheiser 1999; Scott 1998; Smith 1996; Sorkin 1992; Williams 1988; Zukin 1991).

After the storm, these histories of restructuring remain strangely absent in the rebuilding discussions hosted by city and state planning commissions. Nonetheless, they are an important part of the collective memory and discourse of displaced residents, who recall how these top-down policies disproportionately impact black and low-income communities. Public skepticism over current debates about reducing the urban footprint, reintroducing wetlands into the city in the form of new urban parks, or building mixedincome housing in low-income neighborhoods is informed by a mindfulness of long histories of urban renewal and interstate highway and park construction, which caused their own form of devastation in mostly black residential neighborhoods: North Claiborne Avenue, Louis Armstrong Park, the Third Ward, and, more recently, the demolished public housing developments remain as scars in the landscape of the city (Breunlin 2004a, 2004b; Crutcher 2001; Fields 2004; Samuel 2000; see also Haymes 1995).

As with other U.S. cities since the 1950s, urban planners, developers, and government officials viewed "redevelopment" as a way to improve land value and deal with complicated social problems linked to structural racism and class divides by simply "deconcentrating" poverty. This strategy is often linked to a naturalized view that land use should be maximized-governed by highest and best use-negating 
residents' "place attachments" (Altman and Low 1992; Low and Lawrence-Zuniga 2003). Writing about the demolition of public housing, Shari Feldman and Wendy Hathaway have pointed out, "Memories of hardships, personal losses, turnover, and racial transition caused by massive relocation under Urban Renewal should signal caution about unintended effects [of similar policies]" (Feldman and Hathaway 2002; see also Greenbaum 2002). City residents unaffected by these earlier redevelopment policies may be unaware or unconcerned of their large-scale impact, and thus do not factor them into the post-Katrina rebuilding dialogues. For many African Americans, however, the poststorm diaspora is lived through a collective memory of multiple diasporas, including those experienced by New Orleanians when their homes were torn down in the name of "progress." 1

In 2001, when only a few buildings of the Desire Public Housing Development remained, we spoke to a former resident who was visiting her elderly mother. Surrounded by acres of vacant land in the Ninth Ward, she said:

I grew up with my neighbors eating my food. Yeah, and we ate their food. They-[the city] don't think about that, they just looking at the quality of the land. "I could put a mall there." They aren't thinking about the generations. [conversation with authors, January 14, 2000]

Residents of Desire, Louisiana, did not own the land where they resided and consequently their strong attachment to the social ties embedded in their part of the Ninth Ward went unrecognized by policy makers. Owning land, previously a legal basis for citizenship rights and now a symbolic anchor of cultural citizenship in the United States, remains an elusive goal for many marginalized by the ownership society. As Amahl Bishara writes in regard to another contested terrain (Israel-Palestine), notions of cultural property may serve to ratify specific relationships to land: "Prevailing notions of culture recognize certain cultures more easily than others for reasons often relating to aesthetic and historical contingencies" (Bishara 2003:158).

U.S. citizens are outraged by state use of eminent domain if it infringes on the rights of property owners, but public housing resident's attachment to place is viewed as less significant because it has not gone through a market transaction. Since the storm, many residents have used their status as homeowners to contest possible displacement. Raynard Casimier Sr., a New Orleans pastor and property owner, is quoted in the Times-Picayune saying, "Somebody wants our dirt. Disaster is big money. I want to see my people come back for their dirt" (Filosa 2005). New Orleanians who are renters or who reside in public housing are not only locked out of this discursive strategy, they find themselves outside of federal and local policies for housing assistance. The Louisiana Road Home program, for instance, is geared specifically towards homeowners with severe housing damage. Although state officials have said they will provide incentives for rebuilding rental housing, no specific plans have been made as we go to press (Eaton 2006). In addition, with the exception of the Iberville, public hous- ing developments in the city remain closed, their entrances sealed with new iron doors and windows installed by two companies-Vacant Properties Security Inc. and Accessed Denied-and with chain link fences around their perimeters. In the middle of June 2006, U.S. Housing and Urban Development (HUD) Secretary Alphonso Jackson confirmed residents' fears that they would not be allowed to return to their homes when he announced plans to "redevelop" four of the complexes-B. W. Cooper, C. J. Peete, Lafitte, and St. Bernard. More than 5,000 units will be permanently closed for redevelopment (Filosa 2006).

In response, the Advancement Project filed a lawsuit on behalf of New Orleans public housing residents against the Housing Authority of New Orleans (HANO) and HUD, which stated that agencies have prevented low-income black families from returning to New Orleans since the storm. It also states that the demolition of public housing violates the guiding principles on Internal Displacement, as outlined by the Office of the United Nations High Commissioner for Human Rights. In particular, principle 28 states:

Competent authorities have the primary duty and re-
sponsibility to establish conditions, as well as provide
the means, which allow internally displaced persons to
return voluntarily, in safety and with dignity, to their
homes or places of habitual residence, or to resettle vol-
untarily in another part of the country. Such authorities
shall endeavor to facilitate the reintegration of returned
or resettled internally displaced persons. [UN Office of
High Commissioner for Human Rights 2006]

By not opening public housing and failing to provide basic services such as health care and public education, many displaced residents and their advocates believe that local, state, and federal governments are violating their basic human rights (Sasser 2006). These changes can be said to represent, in a condensed temporal frame, many of the same processes recognized in other contexts as elements in the global restructuring of cities. In New Orleans, as in other globalized cities, one discerns dramatic "reconfigurations of wealth, social space, and urban citizenship" (Zhang 2002:312).

As in other displacements, people unable to return to New Orleans are losing more than just shelter. The social networks they developed over generations are also threatened (Breunlin 2004b; Stack 1974, 1998, 2001; Venkatesh 2000). Writing about Johannesburg, Abdou Maliq Simone suggests that one way to think about an urban area after "the policies and economies that once moored it to the surrounding city have mostly worn away" is to consider people as "an infrastructure-a platform providing for and reproducing life in the city" (Simone 2004:411, 408). It is the residents of the city who find ways to reconnect, to cross boundaries, and to build new ways of interacting with meaningful places in their lives-even if they have been dramatically transformed. As New Orleanians return home or find their city is now only a place to visit, their travels, relationships, and informal and formal methods of organizing will have an important impact on the city's recovery and 
place making in spite of (or in response to) the top-down policies being implemented.

\section{THE SUBALTERN MAINSTREAM}

Since the beginning of the city's history, poor and workingclass black New Orleanians have been forced to live in ecologically and economically marginal land. In these areas, property values remained low, schools were segregated and then abandoned by the majority of white citizens, and job opportunities remained limited. In the last decades of the 20th century, Louisiana had the highest per capita incarceration rate in the nation and was continually listed among the states with the highest rankings in measurements of poverty, unemployment, crime, and diabetes. It also ranks among the lowest in literacy, insurance coverage, and public funding of the arts and education. The aftermath of Hurricane Katrina can be viewed as part of a much larger pattern of structural violence affecting lowerincome residents of the majority black city, a disaster of longue durée.

Yet, for as long as black New Orleanians have been marginalized, they have also created their own organizations that constitute a subaltern mainstream. For hundreds of years, African American communities have organized themselves into social clubs in the New Orleans second-line tradition, participating in a long-standing sociopolitical tradition of self help, mutual aid, and resistance to structures of oppression. They also publicly register their refusal to be defined by others, by the mainstream media, and by the depressing statistics that typically describe their communities. They create their own social networks, institutions, and events that provide opportunities for public recognition and esteem. Although invisible to other sectors of society, individual and larger social identities develop that are nonetheless extremely powerful in their own communities. From an early age, young people are welcomed into what poet Kalamu ya Salaam calls a "spirit family," which broadens kinship beyond bloodlines through the participation in communal events (ya Salaam 2000:28). Perhaps most central to this subaltern mainstream are the Sunday afternoon second-line parades, which have engulfed the streets of New Orleans for more than one hundred years (see Regis 1999, 2001).

Second-line parades are organized and paid for by social and pleasure clubs, the contemporary descendents of 19thcentury benevolent and mutual aid societies, which provided health, unemployment, and burial insurance for their members. The term second line refers to a rhythm, a dance step, and a performance tradition said to have originated in 18th-century Congo Square on the margins of the colonial city, where enslaved Africans, free people of color, and Native Americans gathered, along with a few onlookers, to engage in commerce, music, dance, and religious ceremonies. According to the foundational mythicohistory advanced by a number of community activists and historians, the city's distinctive second-line traditions originated in a freedom dance performed on the margins of a slave society. Born of suffering but also of longing for freedom, second-line parades continue to speak to the contemporary struggles of the city's majority black and working-class population. Following Steve Pile (2005), it can be said to constitute a dream work of marginalized communities.

Parades invite an embodied knowledge of the city experienced at ground level among a multitude composed of club members, brass band musicians, and a heterogeneous cohort of marchers, dancers, and second liners often numbering from 2,000 to 10,000 people (see Figure 1). Like the structure of many performances in both sacred and secular realms of African American culture, the parades are interactive, participatory, and often break down the barriers between the audience and performers through call-and-response as well as dancing. Participation in the parades leads to recognition in other social realms. As one club member explained, "Being a part of these activities, you meet people. Or people know you. That's how I got to be known because I was always involved with something in my community" (Breunlin 2004a:22).

In this article, we have been inspired by geographer Nicholas Blomley's (2002) analysis of alternative concepts of land ownership and value that are not usually recognized in capitalist discourse. Although anthropologists have long been interested in collective land ownership (see, e.g., Meyers 1992; Roseman 1998; Verdery 1998; Zhang 2001), it is rarely evoked in the context of the contested terrain of North American cities where residents participate in a capitalist economic system but may still have alternative ways of understanding place. Blomley urges us to listen to the dense vernacular histories embedded in everyday urban landscapes-to the stories of those who "build, [were] born, fought, loved, died on the land"-not, he warns, "as an exercise in nostalgia" - but rather as a window onto the many ongoing enactments of property as social relations created in the lived spaces of the land (Blomley 2002:569, 567). In Western capitalist societies, property may be public, but it is rarely imagined as collective. Playing on the various meaning of the words settle and settlement, he seeks to unsettle our naturalized understandings of property: "The definitional authority of the ownership model is deemed valuable in part, because it 'quiets' title" and it "ignores the claims and aspirations of many" (Blomley 2003:xv). Recalling the generative insights of Marxian analysis, he suggests that we think of property as "a bundle of relationships" rather than as "a spatialized thing" (2003:xv). The focus on the performance or enactment of social relations of property allows us to consider "the possibilities that property in the urban heartland may be differentiated and diverse" (2003:xv).

In this light, second-line organizations' public performances claim a space in public discourse for alternative notions of value, land, and dwelling together in place in the restructuring city. What is more, club members have been generating alternative ways of thinking and being in the city - the subaltern mainstream of the second line-that are now being deployed by exiled New Orleanians reconsidering their relationship to the city. 


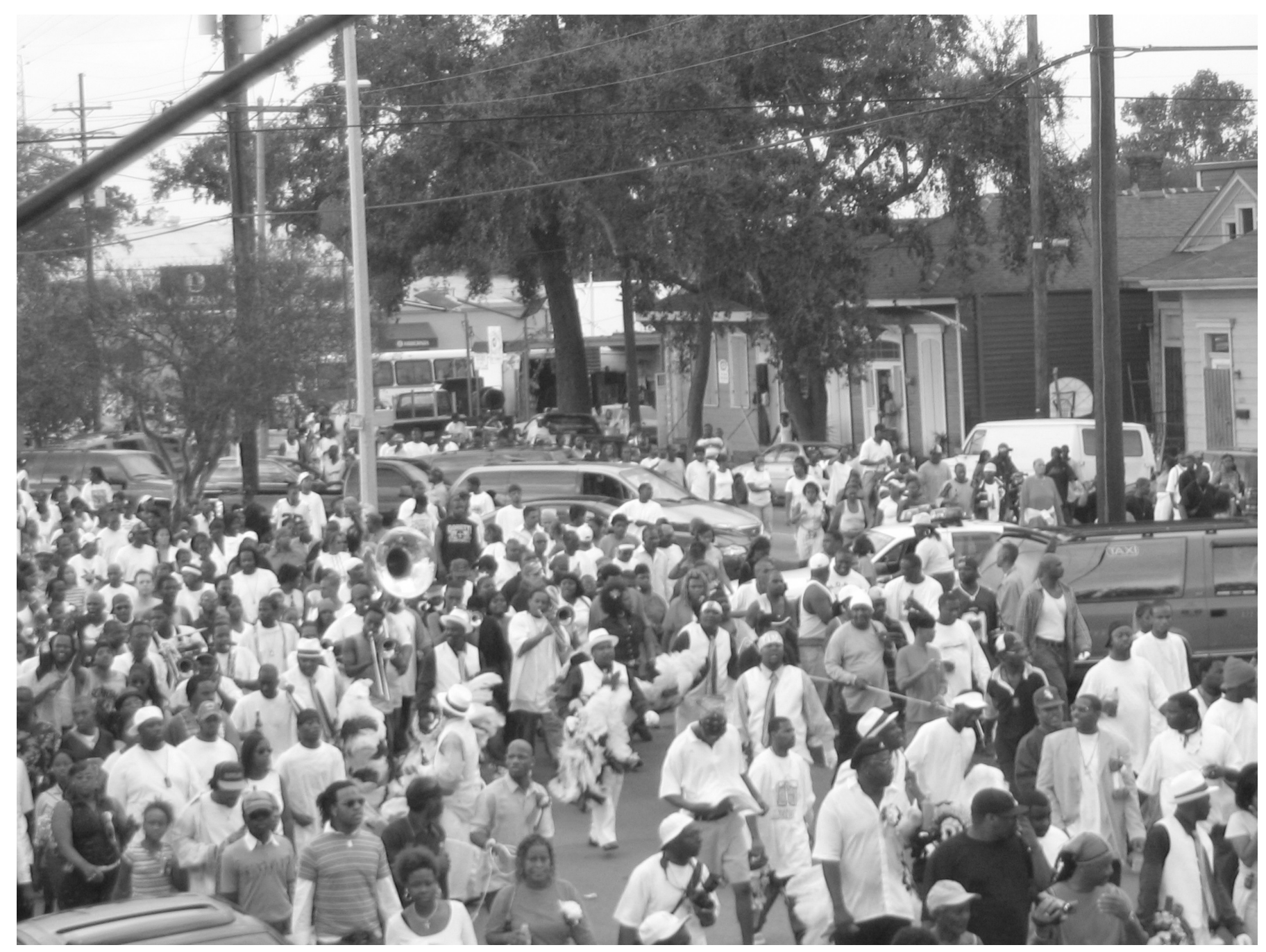

FIGURE 1. Filling the street during the 2004 anniversary parade. As Raymond Williams put it, "It was like a reunion" (conversation with authors, June 2005). (Photograph courtesy of Arlet Wylie)

\section{RESEARCHING DESIRE}

Over the last few years, we have developed a dialogue about the role of second lines in community building and restoration-these conversations began as we would run into each other at Sunday afternoon second-line parades. One of our central themes has been how the performances provide a space for geographically separated friends and neighbors to reconnect (see Breunlin 2004a; Regis 2005). Following national housing policy, New Orleans began to tear down many of its public housing developments in the 1990s and the first years of the new millennium. We discussed how this process would affect the parade routes of social organizations previously based in or near public housing complexes, and how new locations might transform the manner of parading in urban and suburban contexts. ${ }^{2}$ In 2002 , Breunlin organized a photography exhibit and symposium on the fate of public housing residents displaced from the St. Thomas and Desire developments (Displaced 2002). Regis began to follow the rise of new social clubs in suburban eastern New Orleans. We began to discuss ways of researching and writing about the relationships between performance and the built environment, as well as between housing policy, political economic processes, and the social fabric in communities that sustain the performance traditions for which New Orleans is so famous: the culinary arts, music, and the performances of Mardi Gras Indians and social and pleasure clubs (Ehrenreich 2004). ${ }^{3}$

The ethnographic research for this article emerged from a community documentary program Breunlin codirects in New Orleans called the Neighborhood Story Project (NSP 2005). Based at John McDonogh Senior High, NSP teachers work with teenagers to research and write books about their neighborhoods. During 2004-05, one of the research sites was the Ninth Ward neighborhood of Waukesha Jackson, one of the students in the NSP program. Waukesha interviewed her neighbor, Evella "Ms. Coochie" Pierre, who had moved to her block a few years ago when the Desire Public Housing Development was torn down. Each year, Nine Times Social and Pleasure Club's second line stopped at Ms. Coochie's house. The parade had fostered a groundswell of 
pride in the neighborhood, so Rachel encouraged Waukesha to find out more about the second-line tradition-the big day when the street was overtaken with people and brass band music. In the interview, Ms. Coochie explained that her son, Louis Pierre, was one of the founding members of Nine Times. In early 2000, he was found shot to death at a bus stop in the neighborhood. The club continues to honor his memory, and Ms. Coochie's involvement in the organization, with a stop along the parade route. It was through this initial interview, as well as our participation in their November 2004 parade, that we learned how the second line has served as a "reunion" for Desire residents who were displaced when their development was torn down in 2002. Moreover, the annual parade serves as a way to reconnect with the souls of friends and family who have passed on. The interviews for the Neighborhood Story Project contributed to a chapter of Waukesha's book, What Would the World Be Without Women? Stories from the Ninth Ward (2005), from which we have drawn in this article.

As Waukesha's book project was winding down, we asked Nine Times members if they would be interested in continuing to participate in some interviews about the Ninth Ward, the Desire residents, and their involvement in second-line parade networks. We spent time with the club at Ms. Coochie's house and at Magee's, a barroom a few blocks away from the development that serves as their "home base," tape recording interviews and focus groups with the members. The last time we saw each other before the storm was at Waukesha's book release block party in the Ninth Ward. Several club members had come to a reading by NSP authors and took pride in the accomplishments of one of their own. At Waukesha's party, Nine Times members surprised her with a second line-and teachers, neighbors, and family members danced with them around the neighborhood and then signed each other's books. The powerful sense of recognition and community ownership of these books and their neighborhood had a profound affect on the club members, and it played an important role in gaining for Rachel (and by association Helen) the respect and trust that would allow us to continue working together.

\section{AFTER THE FLOOD}

In the middle of this research project, Katrina and the storm surge that followed overwhelmed New Orleans. Like 80 percent of New Orleans residents, we evacuated the city before the hurricane and spent the next week huddled around televisions, squinting to identify the New Orleans neighborhoods that were being shown from aerial video footage taken from helicopters. Many of us hoped to see an image of our streets, homes, and neighborhoods. The complexity of the landscape became a surreal blur of motion and water. Early reports indicated that "Ward Nine" had taken the hardest hit. Later, the term was revised to the vernacular, "Ninth Ward," which then became a metaphor for any flooded downtown neighborhood. On CNN, we saw images taken from the city's Seventh and Eighth Wards, among other neighborhoods, and all were consistently referred to as the Ninth Ward.

As people were airlifted from rooftops and dropped off on the ramps and elevated sections of the interstate by neighbors who had "commandeered" boats, a larger public discussion developed in the newspapers and on television about the poverty that the storm exposed and how it was entangled with race. No longer was the discussion about what went so wrong with New Orleans levees and the rescue operation that followed after they failed, but what went wrong before the storm. The Economist (2005) ran a cover story called "The Shaming of America" with an image of a black woman in a New Orleans T-shirt crying. Similarly, Newsweek's headlines read, "Poverty, Race, and Katrina: Lessons of a National Shame," and the cover featured a close-up of Faith Figueroa, a one-year-old black child from the Lower Ninth Ward (Atler 2005). As these stories developed, the Ninth Ward became a metaphor for poverty, race, and neglect as well. The reality of a majority black city seemed to take the United States by surprise. At the same time, poor whites flooded out of their homes in adjoining St. Bernard and Plaquemines Parishes were underrepresented among the images of desperate victims waiting to be rescued. Even now, the more affluent Lakeview, Pontchartrain Park, and Gentilly neighborhoods are not defined by the deaths in these areas in the same way as the Ninth Ward (Filosa 2005). ${ }^{4}$

In Wisdom Sits in Places, Keith Basso develops the idea of "place making," which he defines as the fairly ordinary way that individuals begin to think about particular places and develop a way of understanding what happened there. He writes, "It is a common response to common curiosities-what happened here? Who was involved? What was it like? Why should it matter?" (Basso 1996:5). Although Basso's conceptualization of place making draws on a bottom-up, ethnographically informed understanding of the phenomenon, the concept can also be applied to the top-down place-making processes of global media and national policy. The media coverage following Hurricane Katrina defined the Ninth Ward for the world. People who had never even set foot in the area suddenly became experts on our city's future possibilities and past failures. Self-appointed pundits could be overheard declaring: "Obviously, the Ninth Ward is just going to have to be bulldozed." "There's nothing there to salvage." ${ }^{5}$ For displaced New Orleans residents desperately watching television and seeking information, the disaster of the hurricane and the flood was overtopped by the mediated disaster, as we watched and listened to our city being objectified and distorted by journalists, armed with Google Digital Earth, live satellite feeds, and little local knowledge about the people, places, and communities that make New Orleans home.

If we expand the idea of place making beyond the international media context of natural disaster, it is clear that the Ninth Ward has its own history and relationship to the rest of the city and region. Akhil Gupta and James Ferguson 
(1999) offer a useful perspective on place making as politically contingent process:

\begin{abstract}
How are understandings of locality, community, and region formed and lived? To answer this question, we must turn away from the commonsense idea that such things as locality and community are simply given or natural and turn toward a focus on social and political processes of place making, conceived less as a matter of "ideas" than of embodied practices that shape identities and enable resistances. [Gupta and Ferguson 1999:6]
\end{abstract}

Their suggestion that we look at people's actual practices in the making of place informs our exploration of the social and political making and unmaking of Desire. With this in mind, we consider how others have seen the Desire area and how people in Nine Times Social and Pleasure Club understand their community and react against the dominant discourse about their place in New Orleans.

Talking with us before the flood, Raphael Parker, a member of Nine Times, said he believed that parading gives the club a chance to claim a place for the Ninth Ward and the Desire Projects in the social landscape of the city. As we drove the routes that his club takes through the neighborhood, he explained,

If I was to call the radio station ... and they ask me, "Where you calling from?" "I'm calling from Nine Times." I'd probably have to explain what I'm meaning by saying Nine Times-a certain area where we parade. That's something we created right here. That's something new. [conversation with authors, June 2005]

Nine Times not only produces a parade but also effectively produces a new experience of and representation of neighborhood-Nine Times. It also claims a collective ownership of a landscape that is considered marginal land.

\section{LOCATING THE NINTH WARD}

Historically, scarcity of safe and affordable housing in New Orleans has corresponded with the topography of its deltaic site. The colonial city was built on the banks of the natural levee of the Mississippi River. Areas further away from the river were referred to as "back-a-town" and were originally associated with the "never-never-land between back swamp and natural levee" (Lewis 2003:35-36). These backa-town neighborhoods were built on lower-lying land susceptible to flooding. The topography took on racial as well as socioeconomic significance as freed slaves, migrants, and later Southern and Eastern European immigrants denied other housing options found homes there (see Campanella 2006b). Migrants moving into the city from country towns in Louisiana and Mississippi settled where they had relatives who could take them in and help them to find work and housing. Newest and poorest migrants often moved into areas that were more prone to flooding and often went without basic amenities like water and sewerage. ${ }^{6}$

The city, which was often described as having one of the most integrated residential patterns in the United States with small shotgun houses and Creole cottages rubbing shoulders with grander homes, became increasingly segregated in the 20th century (Hirsch and Logsdon 1992:189200; Lewis 2003:50-52). As drainage and pumping technology advanced, previously uninhabitable swamps near Lake Pontchartrain were drained and the city expanded. Middleand working-class families were able to buy homes in the newly developed areas with Federal Housing Administration (FHA) and Veterans Affairs (VA) loans. However, these federally subsidized programs "redlined" racially mixed and dense inner-city areas and refused to issue loans there (see Hirsch 1998, 2000). Black families who could afford other mortgages were also denied access to new developments through restrictive racial covenants that prohibited anyone other than the "Caucasian race" from purchasing property (Colten 2005).

One of the defining characteristics of the Ninth Ward is its relationship to water and industry. It has been classified as "a low-income section of the city and has endured chronic neglect in terms of city services. The ward's lower sections have been victimized repeatedly by flooding" (Colten 2005:154). There are two main reasons for this repeated flooding. The first is simply topography: The land set back from the natural levee is many feet below sea level (Campanella 2006a). More problematically, a series of manmade canals that connect the Port of New Orleans to the Gulf of Mexico converge in the neighborhood. In the 1920s, the Ninth Ward was split in two when the Port built the Inner Harbor Navigation Canal, commonly known in the city as the Industrial Canal, to accommodate ocean-going vessels between the river and Lake Pontchartrain. In the 1960s, the Industrial Canal was linked to a large shipping canal, the Mississippi River Gulf Outlet, through the Intracoastal Waterway. For years, "MR-GO" has been denounced as a "hurricane superhighway," which funnels storm surges cutting through the swamplands of Plaquemines and St. Bernard Parishes into the New Orleans area. The critique was demonstrated to be true when the Industrial Canal levees were breached during Hurricane Betsy in 1965 and again during Katrina in 2005.

The port activities found along the Mississippi River and the Industrial Canal, as well as a number of drainage canals and railroad tracks, give the area an industrial character. In fact, one of the main ways that residents define where they live is in reference to the Industrial Canal: The Upper Ninth Ward is upriver from the canal, and the Lower Ninth Ward is downriver, between the canal and St. Bernard Parish. Other defining characteristics of the physical and social landscape of the Ninth Ward are structured around waves of housing that developed with pumping technology and other local and federal housing initiatives. The Bywater and Holy Cross neighborhoods, built on the natural levees, are designated national and local historic districts. Further "back-a-town," working-class residential areas developed after World War II as one of the few areas available to black families who were looking to purchase their first homes or to find housing after being displaced from areas closer 
to the center of the city because of "slum clearance" (see City Planning and Zoning Commission 1952; Greater New Orleans Data Center 2005; Lewis 2003: figure 21, pp. 36-37).

The Ninth Ward remained racially mixed through the 1960s, when Orleans Parish Public Schools began desegregation in the neighborhood. Images of white mothers screaming at a small black girl named Ruby Bridges as she was accompanied to William Frantz Elementary by the National Guard made headlines and brought the Ninth Ward into houses around the country. As in the news coverage of Katrina, however, the aftermath of the event was not widely reported: In this instance, white families pulled their children from the school and soon moved into more suburban areas. ${ }^{7}$

\section{SITUATING DESIRE}

\section{Constructing Public Housing}

They call down here the country. When you go Uptown, that's where it all go down.

-Charlene Mathews, Lady Nine Times President (Jackson 2005:76)

In 1956, the HANO opened Desire Public Housing Development in the Ninth Ward as a segregated project for low-income black people. Built near the Industrial Canal, the Florida Avenue drainage canal, the Agriculture Street Landfill, and railroad tracks, the development had 1,840 units and over 14,000 residents, making it the third largest housing development in the country. As one former resident reflected, "It was a city. A city within a city" (conversation with authors, May 2002). Like other public housing developments in New Orleans, Desire's two- and three-story brick buildings were designed around courtyards, which were set off the city grid and celebrated for being a safer environment for children. The structure, material, and layout emphasized the difference between public housing and the surrounding neighborhoods. The city and HANO addressed the ongoing affordable housing shortage but were not willing to acknowledge their own role in reinforcing and increasing segregation. The "checkerboard" residential patterns were exchanged for "concentrated poverty." ${ }^{8}$ On both a national and local level, the creation of segregated public housing has been condemned as a step backwards in social policy_often denounced as producing situations akin to apartheid townships in South Africa (Hirsch 2000).

At the same time, advocates for reform in housing policy and civil rights activists continued to refer to Desire as the prototypical case of structural violence and racism. As poet and essayist Kalamu ya Salaam puts it:

This is a prime example of America' best foot up our ass, [a] replication of the planned destitution of South Africa's apartheid-inspired Bantustans. ... The punitive and punishing brutality of day to day existence in Desire and similarly garrisoned housing projects is horrendous. ...W We languish on this killing-room floor like out-takes from a slave/horror snuff flick; a routinely iced, enchained cast of thousands.
Upwards of eight thousand plus people are corralled into these crumbling brick hot-boxes. ... Desire is a sunlit nightmare. [1988:13]

Desire is a critique of the United States (see also Eckstein 2006:131). But what of the real people who lived there and who saw their lives as having other meanings and other purposes?

Throughout its history, the question of isolation-both physical and psychological-has been an ongoing source of debate among advocates for and against public housing, as well as residents themselves. ${ }^{9}$ In the beginning, the development was seen as a refuge by many families displaced by urban renewal. Frank Lazard, a former resident of the Third Ward, a neighborhood demolished to make way for new developments in the Central Business District, remembers, "Displaced people, they had no place to go and some of the places you rented wasn't decent to live in and at that particular time you didn't have no water, no electric in some places" (conversation with authors, October 2002). In contrast, Desire provided welcome relief from these hardships. "Oooh! I had four bedrooms because my wife had nine children. We were doing all right there" (conversation with authors, October 2002). Other residents moved in from country towns in Louisiana. Parker, as Raphael is known to most of his friends, explains his own family's migration from Terrebone Parish's sugarcane plantations to Desire,

My mother lived on Louisa Street with my grandmother.
They moved from Raceland, Louisiana. Back in the days,
most families were together as one, so they started
branching out. I think my mother and her sister was the
only two that moved into Desire and it was a blessing to
move in there because we did have our own space as a
family. [conversation with authors, May 2005]

At a time when almost half of the housing did not have indoor plumbing and electricity, public housing developments made these modern amenities available to lowincome residents. On warm nights, residents slept outside in the courtyards.

Desire was a new place heavy with symbolism, but without traditions of its own. As Ms. Coochie tells it: "I moved into the Desire when I was fourteen years old. When I first moved down there, I didn't like it. They didn't really have nothing for young children to do but get in trouble" (conversation with Jackson and Breunlin, October 2002). Many residents continued to travel to other parts of the city to participate in the second lines that were so important to the subaltern mainstream. Reflecting on the importance of the parades, Parker says, "That's something you begin to love because that's real New Orleans. That is the culture of New Orleans" (conversation with authors, November 2005). Ms. Coochie, who grew up in the Seventh Ward, took her children to second lines, and her son Louis paraded with the Jolly Bunch and the Money Wasters Social Clubs as a boy. Other Nine Times members participated by joining the huge crowds that followed the parades. Corey Woods explains that, "My daddy, my uncles, all of us-I grew up 
in all of this. They weren't in no club, but they were some second-line people. Second lines are in my whole family, really" (conversation with authors, May 2005). Members also fondly remember an older man named Uncle Pic who gave them rides in his pick-up truck to other parts of the city where the music and parades were happening. Charlene Mathews explains that, "On Sundays, he used to come in the back of Desire and he would pull up. Everybody would be like, 'You going to the second line? You going to the second line?' It was all ages. ... I used to be like, 'Look Mom, what do I gotta clean up and do!"' (Jackson 2005:75).

Over time, Desire developed an identity of its own. Young people who grew up in the development and who placed it at the center of their experiences do not remember the same sense of isolation that Ms. Coochie recalls when she was a teenager. Nine Times members walked to the Lakefront to go swimming, participated in sporting events all over the city, and took city buses to the Central Business District and the Gentilly shopping center. After years of living in Atlanta and other parts of New Orleans, Troy Materre considers the question of isolation:

\begin{abstract}
Cut off from what? We may have had our own world, but we weren't cut off from the rest of the world. We were free to roam; it wasn't like we had to get permission to go out of the project. We all hung in Press Park, by Carver, Gentilly. We all hung in the Florida. Me myself, I hung everywhere. I even hung in the St. Bernard, went uptown. Maybe they were cut off-they couldn't go nowhere. But if you had your parent's permission, to get on the bus and leave the Desire was like a little trip. Leave this world to go see somewhere else; I'll be back. [conversation with authors, November 2005]
\end{abstract}

The Florida and the St. Bernard are other downtown public housing developments, where many Desire residents had relatives and former neighbors. The other places that Troy mentions are black communities in the Ninth Ward and other areas of the city. Although his trips were within the confines of the social and physical segregation of New Orleans, his telling of them recenters the black experienceyoung people in Desire did not necessarily believe their lives were marginal. And contrary to dominant assumptions, even young people without cars had considerable mobility in the city. Troy's comment- "maybe they was cut off" - challenges liberal notions that black people are somehow deficient if they are not among white people. In this statement, Troy proposes a revisionist view of segregation: Through their own social practices and restricted spatial mobility, white people denied themselves access to Desire.

\section{Black Power, Black Arts}

Desire's position in relation to other parts of the city made it an important place in the histories of black activism and black theater in the United States. Free Southern Theater, in the vanguard of the Black Arts Movement, set up its New Orleans headquarters there in 1965, occupying a building that was flooded during Hurricane Betsy. Their decision to locate in "what was generally considered the worst and most dangerous black ghetto of New Orleans" was crucial to their activism and figures prominently in the theater's own published account of its work. Being located in Desire validates the theater's authenticity because it is a "real" ghetto. Thus, the "ghetto" and activist theater were mutually constituted in a powerful place-making, identity-making dynamic. As John Jackson (2001) has argued with respect to Harlem, Desire is materially and discursively constructed as a preeminent black space. "Harlem was created through both race-specific actions (restricted covenants, white-flight, segregation) and class-inflected interests (of realtors, of the black press, and of northern blacks themselves) that constructed the black Harlem we know today from the many Harlems of yesteryear" (Jackson 2001:28).

Roscoe Orman's poem from The Free Southern Theatre's oral history collection (Dent et al. 1969) illustrates the pull to this place that was set apart from the other areas of the city:

\author{
Driving down slinky New Orleans \\ Turns me on \\ And makes me sad \\ Out in Desire \\ Where the Jazz City funk floats \\ Over the street holes... \\ All beauty in chains \\ Rumbling deep somewhere-between-the stomach- \\ and-the-brain \\ Oh the day will come \\ Out in Desire \\ The day will come.
}

Desire becomes a metaphor for the rise of black culture. Black music may no longer float, intermingling with daily life, but converges into a catalyst for radical politics. Such musings haunt our conversations now, as planners, architects, army engineers, real estate developers, and environmental justice activists ponder the future of the city. "How do we build it better," ask numerous pundits, "without building Las Vegas or Disney World? It must be real, authentic."10 Must it then reproduce the residential segregation and concentrated poverty that made such neighborhoods as Desire famous?

The Black Power movement continued to grow when the Black Panthers established a base in Desire in 1970 with the intention of ridding the development of police brutality and promoting self-determination. As one resident relates, "There was police brutality. The Urban Squad used to beat the hell out of us. They had the Urban Squad under Moon Landrieu. They used to come back here and whoop us. Throw us on the ground, arrest us, throw us in jail for no reason" (conversation with authors, May 2002). Deejay (DJ) and Black Panther documentarian Brice White interviewed Black Panther Malik Rahim, who recounted how his organization survived a face-off with the police:

When we opened our second office in the Desire, 600 police came the second time. 600 police, National Guard, and State Troopers. And then almost 5,000 people came 
out of the Desire projects and stood between the police and our office and refused to move. That was the reason we survived the second shoot-out. [White 2004]

Desire was on the front pages of newspapers around the country as tension between activists, residents, and the police built to a breaking point. Even Jane Fonda made her way into the fray, driving limousines into the city with offers to rescue the insurgents.

Events of this period were the subject of sensationalizing media reports and misinformation. But counterhistories, retold by residents and activists, rarely make their way into print. Ms. Coochie remembers, "People really thought the Black Panthers was a threat to the area, to the community, but they were not a threat. They were in the community to help people. They'd feed the children breakfast, and after school they'd help them with their homework" (Jackson 2005:69). Several Nine Times members remember eating breakfast before going to elementary school. Parker recalled for us his youth organization's marches on City Hall:

I remember the Black Panthers: the black suits, the black hats. But actually they were some good people, to tell you the truth. One of my mentors who raised me, Alvin Kennedy, was a Black Panther himself. He was a mentor for the whole Desire from the sixties up until 2000-a new century. He had a club called The Young Men of Desire, which I was a member of. We marched on City Hall's front lawn. I was one of those kids [on the nightly news]. [conversation with authors, November 2005]

Although the media focused on the Black Panthers' national profile, it was the local members who continued to make an impact in the housing development. Like the second-line parades, the political activism connected young people to other parts of the city and helped them gain recognition for their own community. As with social and pleasure clubs, it is not just the high-profile events that the Young Men of Desire staged that resonate years later but the care-taking ethic that continued on a day-to-day basis. "Brother Twin," as Alvin Kennedy was affectionately known, was a father figure to many "young gentlemen," and it is the "plenty of cheese sandwiches on Saturday mornings" that made a lasting difference to the community.

\section{DJs}

One time we had a culture that was so rich ... so deep. At night we'd go out in the street and dance with speakers and a big old light shining from somebody's window.

-former Desire resident, conversation with authors, May 2002

In the 1980s, the federal government's commitment to safe and affordable housing was beginning to wane. HUD funds for public housing were cut by more than 80 percent, causing buildings in Desire to deteriorate. At the same time, national policies dismantled War on Poverty programs to focus attention on individual "pathologies" (i.e., sub- stance abuse, nutrition, and teenage pregnancy) that did not address the structural racism embedded in unequal access to health care, day care, education, and well-paying jobs (Martha Ward, personal communication, September 5, 2006; see also Ward 1986, 1995). Desire residents filed a class action suit in federal court against former New Orleans mayor Moon Landrieu, who was now serving as HUD Secretary, and HANO, alleging that parts of Desire are "unfit for human habitation" (Times-Picayune 1979). Long-term resident Ora Price, speaking with Rachel in 2002, when there were only a few buildings remaining in Desire, explained:

\begin{abstract}
The turn around was in the 1980s. Things started getting bad for us. The government let the infrastructure go down on purpose and then they blamed us for tearing up the place. But really, they let the place go without any sort of renovation for so long-you know anybody's house is going to get damaged from weather: wind, rain, floodwe've been through all of this back here.

All day and all night, they'd run those drugs out of the hallway. I used to take hot soapy water and throw it down the stairs. They got so used to me running them out of the front hallway, they'd go around the back. And when they'd come around the back, I'd be at the back door. [conversation with author, May 2002]
\end{abstract}

Thus, disinvestment in the physical infrastructure coincided with the intensification of drug economies, uneven policing of street dealers, and the concentration of streetlevel dealers into public housing areas.

For Nine Times members, navigating through the complicated terrain of Desire required a combination of parental support and street smarts. Although some parents tried to protect their children from the drug dealing in the development by keeping them "inside," Nine Times members argue that being given enough freedom to understand the social geography of the area was actually important in avoiding trouble. Parker uses the example of "store runs" to illustrate how small excursions through the development to a corner store can help teach children how to avoid the "left hand stuff":

When you're going to the store, you're seeing things, you're learning things. Some parents don't let their kids go to the store-they'll make them stay inside and go themselves. Now they don't know the short cuts to the store. Don't know how to get around things and go straight into problems. They got dark spots where they knock the lights out, places you know you're not supposed to be in. You got to know all that. That's not a good area in the daytime. You got to be outside to know. [conversation with authors, November 2005]

Members argue that this kind of local knowledge-what James Scott calls a "special geographical dialect" (1998:54, 313) — was only possible to attain through participating in the social life of the community. In doing so, young people develop practical skills to respond to a changing environment.

In the 1980s, when the development was gaining a citywide reputation for violence and crime, music became a 
route into the community as area residents produced their own distinctive DJ scene, fostering the development of a distinctive New Orleans sound-and-dance style that would eventually join the weekly parades around the city. The DJ phenomenon in Desire corresponded with a national movement in places labeled "black holes of urban blight" by policy makers. These massive block parties produced a new style of music that "tropes Langston Hughes saying I'm still here!" (Baker 1993:90). Houston Baker explains the archiving "Black sound" that contributed to creating hip-hop: "African drums, bebop melodies, James Brown shouts, jazz improves, Ellington riffs, blues innuendoes, doo wop croons, reggae words, calypso rhythms... were gathered into a reservoir of threads that DJs wove into intriguing tapestries of anxiety and influence" (Baker 1993:89).

In Desire, this phenomenon produced another kind of place making, as those very sites devalued by public policy were being reinvested as dynamic soundscapes, through the embodied performances of participants in the DJs. Whereas Desire residents previously had to leave the development to participate in many of the cultural activities around the city, people were now beginning to travel to the Ninth Ward. Desire's courtyards provided a place to set up a sound system with heightened acoustics and plenty of room to dance. ${ }^{11}$ Troy remembers, "Just being in that Desire was something to be. Especially on the weekend. DJs! Action on the weekend" (conversation with authors, May 2005).

As a new generation embraced hip-hop and were "into break-dancing, the electric boogie, rap," they consequently influenced a new generation of brass band music and second-line culture. New bands such as the Dirty Dozen Brass Band, the Pinstripes, and later the Rebirth Brass Band, the Tremé Brass Band, and Soul Rebels took the Traditional Jazz sound associated with second-line music and infused it with the contemporary sounds of funk, blues, and rap (see Burns 2006). Just as hip-hop had emerged from a call-andresponse between DJs and break-dancers, this new brand of brass band music developed as a group creation (see Ashe 1999). The revitalized sound also brought a whole new generation of second-line dancers and music lovers into the performances and the business and social clubs that nurture them.

In the late 1980s, when Helen first began participating in these parades, nearly every social club either started or ended their routes in a project, or they passed through a major housing development during their Sunday afternoon anniversary parades. When second lines move through the projects, the crowds swell in number as they move through densely populated settlements, and the raucous sounds of the brass bands echo off the brick walls of the apartment buildings. The Soul Rebels Brass Band recorded a tune in the mid-1990s that spoke to the close bonds between secondline performances and the city's housing projects. In a politically conscious rap, the lead singer calls out to global citizens to stop the killing "here at home: in Washington, in Dallas, Seattle, Miami, Detroit, New Orleans, Los Angeles" as well as "South Africa, Bosnia, Haiti ... Northern Iraq, Northern Vietnam, South Vietnam," going on to name the city's projects in the same breath, "The St. Thomas, the Magnolia, the Calliope, the Iberville, the Lafitte, the St. Bernard, the Florida, the Desire, the Fisher" (Soul Rebels 1994). As the Soul Rebels lyrics seamlessly move between the war zones of cities, nations, and housing projects, they call on us all as citizens and subjects of territorialized communities to end our mental slavery, urging: "Let your mind be free. Stop the killing. Stop the killing. Stop the killing" (Soul Rebels 1994).

\section{OUT OF DESIRE \\ Putting the Ninth Ward on the Map}

After years of joining second lines, participating in other clubs, and dancing at DJs in Desire, Louis Pierre, Raymond Williams, Richard Anderson, Raphael Parker, and Troy Materre decided to organize a second-line club "out of the Desire." Started in 1998, the club was called Nine Times. Ms. Coochie recalls,

I kept telling [Louis] it wasn't going to work out. When you say parade, you're talking about serious money. [But] he was determined to get a club out of the project. And he wound up really doing it. My cousin took and christened their banner for them and they all cried, because a lot of people said they weren't going to make it. [conversation with Jackson and Breunlin, December 1, 2004]

You can hear Ms. Coochie's pride as she recounts her son's defiance of structural constraints-geographical isolation, chronic unemployment, and economic scarcity in the project-as well as his family's and neighbors' skepticism.

In this light, we can see that second-line organizations' public performances claim a space in public discourse for alternative notions of value, land, and dwelling together in place in the restructuring city. Moreover, Louis and his fellow club members in Nine Times were generating alternative ways of thinking about the land, about public housing, and about a place named Desire-an area so often represented in the news media as a place of disorder, alienation, and violence. Parker articulates how the parade challenged the misconceptions that circulated around the project:

It's just a good feeling when you got your true loved ones you've been coming up with from knee high and everybody there for you, just supporting you while you try to make a stand where God raised you up at, being a housing complex and all. You know, let people see that everybody ain't just crazy and deranged. [conversation with authors, June 2005]

Nine Times's parade provided an opportunity for club members to represent their neighborhood to the larger network of social clubs and second liners around the city. Yet it was also a way of renewing ties and building solidarity within their own community. The moment that defines this interchange is at the beginning of the parade, when a crowd gathers to wait for the club to emerge from a house, barroom, or another community spot. As the band begins to play, one by one, members dance out the door into a street full of people. Lady Nine Times Grand Marshall Jean Nelson explains, 
It's a beautiful feeling. You have to try it first in order to know. To get that rush coming out that door. It feels scary and everything when you see all the people. Girl, but once you get out there you just go all out and do whatever you have to do. It just be beautiful. [Jackson 2005:76]

The moment of crossing the threshold is punctuated by the throbbing bass of the tuba and shouts from the crowd of supporters, close friends, family, and members of rival clubs. The threshold is a spatial-temporal portal, from which one emerges as an individual and simultaneously a member of something larger. For first-time paraders, crossing that threshold is an initiation, which binds them powerfully to a collective that encompasses the living as well as the ancestors. Club members dance together creating a circle bounded symbolically by a rope and the second-line crowd surrounding them turns into a moving social landscape. Troy explains, "When I'm in that rope, I'm in another world I can't even explain. I hear them and I see them, but I'm in my world. Inside this circle" (conversation with author, November 2005). This heightened experienceboth collective and individual-can be equated with the altered or trance states experienced by shamans, healers, and spirit workers throughout the world. It is also the culmination of a year's worth of thought, preparation, and a lifetime of relationships grounded in a particular landscape.

\section{Organizing Routes}

It's one of the first official second-line clubs from the Ninth Ward that got off the ground. It's like a big step for the Ninth Ward, because we never actually had it done downtown. Nine Times put the Ninth Ward on the map when they parade.

-Jackson 2005:76

Putting together a parade route is a complicated organizational task as club members must simultaneously consider time limitations, their club's social affinities to particular locations, and the condition and "street feel" of small streets, busy avenues, and boulevards. Although second liners can join in a parade wherever they want, the organizers of the club plan for months to make sure their parade will go smoothly. Spontaneity and improvisation as well as rigorous organizing and long-term planning all go into the making of a successful parade. The first factor to consider is the constraints dictated by the city. Although second lines in the past could wind through the city for eight to 12 hours, today's clubs must submit a route that can be completed in four hours to be eligible for a police permit. According to Parker, "We have to go by time. They want us at the headquarters, where we started at-Magee's [barroom]—if we don't do it in four hours they will cut it off." The parade goes as far as Franklin Avenue, which separates the Eighth and Ninth Wards. "We want to try to keep the route in the Ninth Ward. So that's one reason we only go that far" (conversation with authors, June 2005).

To advertise their parade, members leave route sheets in barrooms and pass them out to friends, family, and in the neighborhoods in which they are planning to parade. The best way to let other people know about the parade, however, is by attending other second lines, particularly in the weeks prior to their own parade. Parker explains, "The kinds of people that are involved in parades, some of them don't need route sheets, they just need to know who's parading that week. They basically know the area they gonna be in" (conversation with authors, June 2005).

We had an opportunity to drive Nine Times's most recent parade route with Raymond Williams and Parker on a Sunday afternoon in June of 2005. Driving over the Galvez Bridge, over the railroad tracks, and into the Desire area of the Ninth Ward, we entered a different physical and social landscape of New Orleans. Many of the architectural features of the old city were recreated in the vernacular building styles, but with more modest features. Some houses have a brick veneer over wooden weatherboards, which is a symbol of stability and class to many New Orleanians (and can be found echoed in complements such as "My mama, she was a brick house"). Most are set back from the street with small wrought-iron or chain-link fences enclosing well-maintained front yards. This experience of driving the route with club members allowed us to see how each street, each turn, and each stop in the parade is imbued with meaning for the organizers and paraders.

Parker: Higgins and Press is mostly where we turn and everybody is hyped right now because we're coming to our first bridge, which is part of Nine Times tradition and it will always be. Actually, we can't avoid missing one of those bridges to continue the route. It would have covered a bridge-the Almonaster Bridge, the Galvez Bridge, the North Robertson Bridge, the N. Claiborne Bridge-one of those bridges was gonna be involved in the parade no matter what.

Raymond: We like to look from the high part of the bridge just to look at the crowd that's following us. And that kind of makes us feel more good about that because we've got a crowd that's, you know-

P: And you can see them.

R: How many people we brought here. We can see how many people we brought here down in the Ninth Ward. Back in the days there was no second line at all in the Ninth Ward. [conversation with authors, June 2005]

Given the contested history of the Desire area's geographical isolation, it is significant that Nine Times members view their route's inclusion of bridges in positive terms, as enacting their collective ability to cross boundaries. St. Claude Avenue-without a bridge-is where those traveling in from uptown often meet the parade. Raymond explains,

At St. Claude, we have to rest right there. We look around and try to see how many people are gonna be sitting out here on St. Claude, waiting on us, you know. And then we look around and say, "Wow, man, they got people still coming." You know. Sometimes the clubs [will] go to another second line uptown and they'll meet us here 
on St. Claude. That's what the majority of all the uptown people do. [conversation with authors, June 2005]

Even for those who have participated in uptown parades for many years, venturing into an unfamiliar neighborhood behind a relatively unknown club can be a bit intimidating. As one second liner put it, "If I don't know people in that area, I don't have anywhere to go. What if I have to use the bathroom? And what if they start shooting?" The importance of social ties in a parading neighborhood as a site of respite and refuge is crucial to creating a sense of security for second liners walking miles behind a parade. Yet the music and promise of conviviality nonetheless manages to draw people out of their usual comfort zones. Over time, newcomers may make friends at Ninth Ward parades and look forward to returning next year as guests rather than strangers.

\section{Sweet Water: Creating Stops, Building Community}

For the parade organizers, situating stops on their route may publicize long-term relationship between club members and friends, family, neighbors, or business owners in the community, especially owners of local barrooms. But designing a new route may also allow for spontaneity in creating new social/spatial connections. Raymond illustrates how they can develop: "One day I came out here and I passed the paper out [announcing the parade]. The lady just stopped, and she say, 'What y'all doin?' And we told her we were having a second line and we were passing through here. And I asked her, "Well, ma'am if it's okay, could we stop at your house?" At she told us, "Yeah. I'd be happy to do that-let y'all have a stop here." Raymond may have been looking specifically for a stop in that area to break up a long stretch of walking. But the genuine sense of openness and willingness to extend trust to a new neighbor is also a crucial aspect of the identity of Nine Times.

Including a barroom on a route can make it better known and thus constitutes free advertising for a locally owned business. Bar owners who display generosity and hospitality to club members may find their generosity returned in abundance: "At one time nobody knew about Sweet Water-but now everybody go out there to have fun. And enjoy themselves." Raymond proudly narrates his organization's ability to promote a neighborhood business and advocates a moral economy of "spending locally." "A lot of people goes uptown and spend money uptown, and like we always say, why not let people down here spend money. Let's give our community some love." Similarly, small-scale entrepreneurs with ambulatory food and drink stands step up their carts and trucks along the parade route to the delight of thirsty and hungry second liners. "Some people cook their little food and put their little stands outside. You know. And then it's good to see people buying from these people" (conversation with authors, June 2005).

We are all four riding now north on Louisa Street, heading back toward the home base of Nine Times, a barroom called McGee's, as the sun is beginning to set. Here, the small bumpy side streets give way to vast tracks of land left empty by the demolition of Desire. Suddenly the atmosphere changes palpably as Raymond and Parker recall their experiences parading on the home stretch back to the start (and end) of the parade:

Raymond: This is our heart. Once we get on this street, we know we home.

Parker: We're heading home. Everybody hollering, "Let's go home" and "Let's bring it home" and your legs gonna be saying the same thing.

\section{LOSS AND RECOVERY: THE LAND AND THE SPIRITS}

In all the years that Nine Times's parade has claimed a space for the Ninth Ward and Desire in the second-line tradition, HANO has been in the process of tearing down the development as part of a HUD initiative called Hope VI (see also Walker 2005:137-155). Created by Congress in 1992, HOPE VI (or "Housing Opportunities for People Everywhere") was purportedly intended to eradicate severely distressed public housing by the year 2000 either through the rehabilitation of existing units or through demolition and replacement with hard units (i.e., actual housing, as opposed to Section 8 vouchers). Raymond considers what was lost: "They took a lot away from us, to be honest with you. It took a lot from us because Desire was mostly our home. It was hard to leave there. You know, it's where you grew up!" (conversation with authors, June 2005). Parker explains the attachment many people have to Desire:

It was what we had. You know what I'm saying? And some of us were fortunate a whole lot, everybody wasn't aware of that like you're supposed to be in life. It's something I will never give up in life and if I had to change it, I wouldn't change. [conversation with authors, June 2005]

The community that is remembered with longing by the former residents of the complex should not be romanticized. As Miranda Joseph (2002) has argued, the romance of community erases social exclusion in praise of fictional unities and solidarities (see also DeFilippis and North 2004). As the project began to be torn down and Nine Times members were scattered around the city, Louis Pierre was lost to violence. ${ }^{12}$ Social relationships suffered as individuals slipped out of reach; many struggled with addictions, mental illness, and despair about improving their economic positions (see Newman 2000). But for those who survived, their individual and collective struggles form a core part of their identities. Remembering those who lent a hand, who mentored them, and simultaneously remembering those who succumbed to the pressures around them, Nine Times members honor the memories of all those who were part of their community and through them recall their own struggles. "If someone wasn't able to finish middle school ... went the left-hand way ...they always in our hearts-cause they have a heart" (conversation with authors, May 2005). 


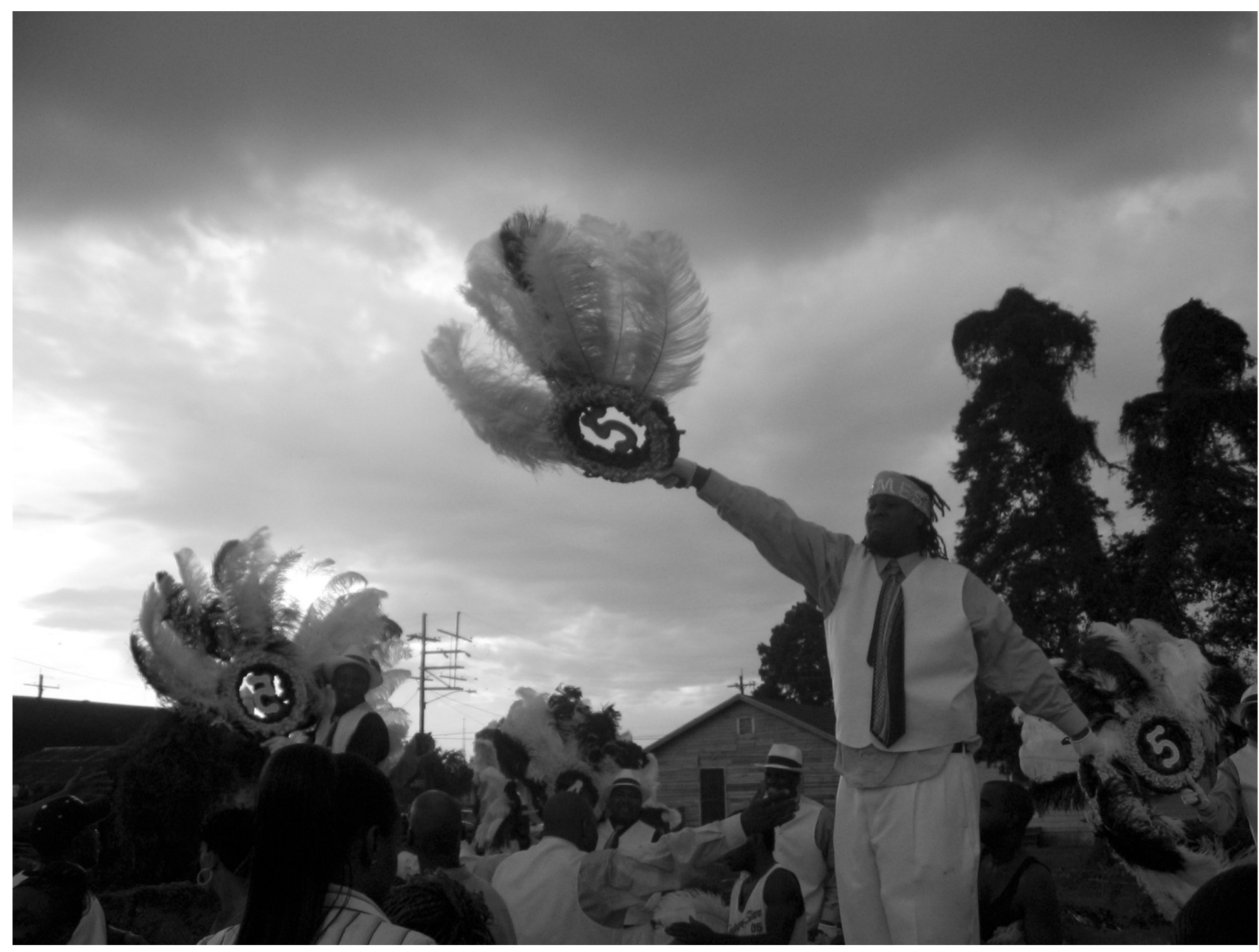

FIGURE 2. Standing on the bricks salvaged from the Desire Public Housing Development. At the conclusion of their annual parade, members posed on these remains, which at sunset feel like ruins of home. The bricks were salvaged by the owner of McGee's bar, the home base of Nine Times. (Photograph by Rachel Breunlin)

The land on which the Desire complex once stood remains sacred land for those who once lived there (see Figure 2). Blomley's (2003) suggestion that we consider the multiple social relations of land and property seems particularly apt in this context. Those relations become visible precisely at the moment when those social relations are constituted, contested, dismantled, and remade. Parker and Raymond seem to be reflecting on these very issues as they discuss their ongoing relations with the place:

Parker: It's the same ground-what they built on it—

Raymond: A lot of people say that-because of those houses, that don't mean nothing, they still will say, "Hey, I stay back there in the Desire."

\section{P: But they say new Desire now.}

R: It was mostly like a reunion, because when the Desire projects were torn down, we moved separate from the area. When people came back to the area of Desire, it was like a re- union. Most everybody was hugging each other. It was hugging, kissing, and shaking hands, the whole parade. [conversation with authors, June 2005]

These comments were recorded in the summer of 2005, but they echo strangely now with the debates about the uncertain demographic future of the city and the discourse of a "new New Orleans." Those who see the devastation of the city as an opportunity for a new beginning or for unmaking past mistakes constitute multiple perspectives and positions. Some have fantasized publicly about a city unencumbered by a large underclass. Others see opportunities for smart growth and more sustainable urbanism. The new Desire and the new St. Thomas have been suggested as models for mixed-income developments in the city after Katrina. Developers who participated in the Hope VI public-private partnerships forged in the "revitalization" of public housing complexes in the 1990s stand well positioned to profit from some of the proposed redevelopments in flooded areas of the city. In this context, it is not insignificant that 


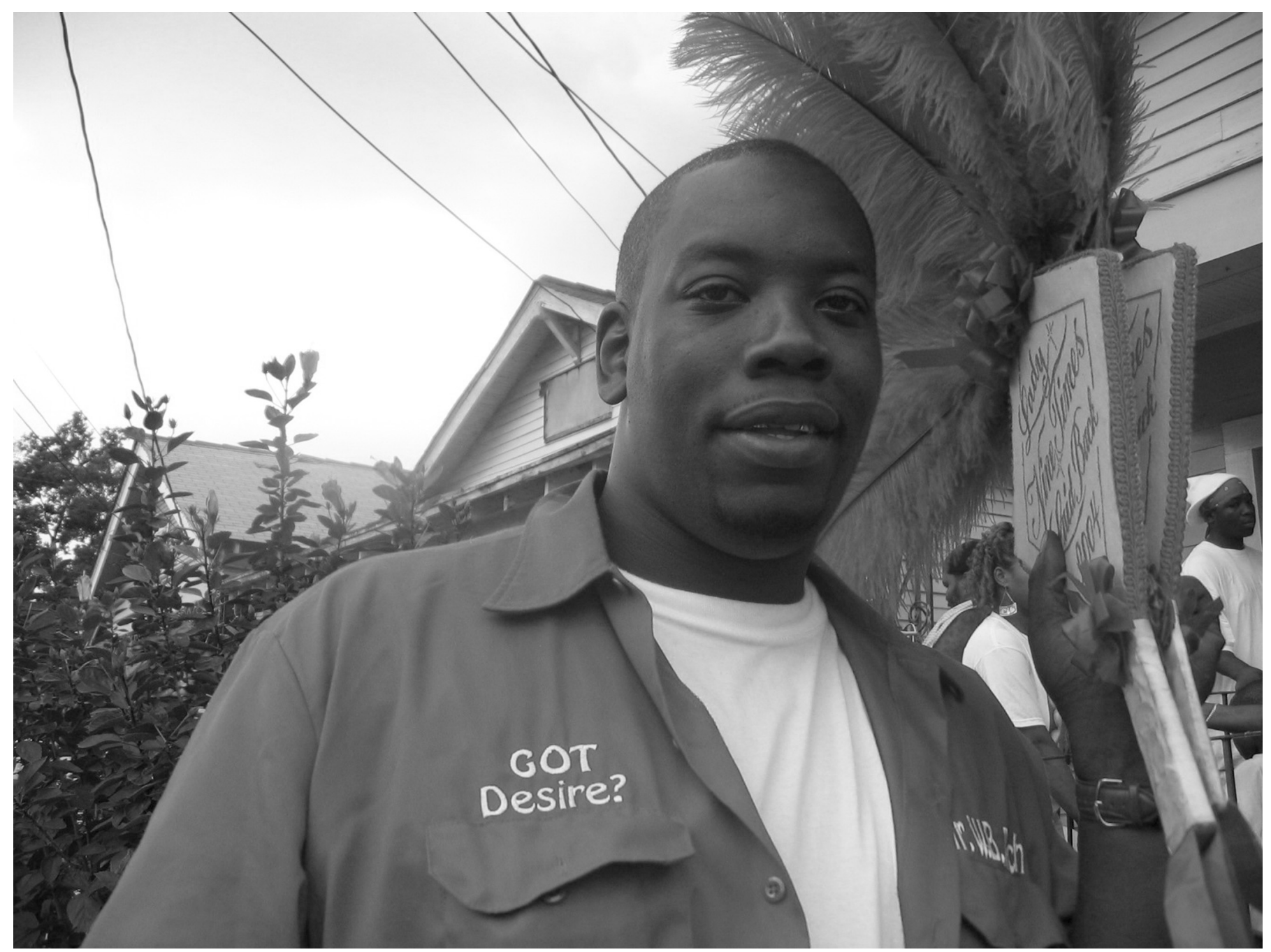

FIGURE 3. "Got Desire?" was the unofficial slogan of the 2004 anniversary parade. The shirts were designed and distributed by friends and supporters of Nine Times in preparation for this parade. (Photograph by Rachel Breunlin)

Nine Times was denied permission to parade through the new Desire apartments during their last annual parade in 2004. If the "new New Orleans" is envisioned to reflect the new Desire, the second-line communities risk being further marginalized from the place they call home.

At the 2004 parade, friends of the club appeared with embroidered shirts playing on the popular "Got Milk?" advertisements of the American Dairy Association with the catchphrase "Got Desire?" (see Figure 3). This unofficial slogan of the 2004 Nine Times parade would seem to evoke the very issues theorized by Blomley regarding the overlapping forms of ownership that continue to be asserted by city dwellers - but are routinely silenced in our naturalized understandings of private property denoting a singular relation to the land. Former residents of Desire continue to make a collective claim to a place (Desire) and continue to enact a dream that is both a memory and a longing for a relation to New Orleans that will not be contained by any one definition of property.

Do the spatial practices of social and pleasure clubs have a role in informing the rebuilding of the city? How do citizens' own understandings of the social relations of property and of their relationship to the land speak to the issues being debated by the city's numerous planning committees and commissions? More specifically, what precisely is lost when people's relation to place is severed by displacement? As of this writing, the Bring New Orleans Back Commission reports refer to social and pleasure clubs and second lines as important cultural resources that are significant to the rebuilding of the city's tourism industry. However, they do not recognize social and pleasure club members or leaders as important interlocutors or shapers of planning policy. Their expert knowledge about producing conviviality in urban spaces is unacknowledged. And their rights to the city based on cultural citizenship (if not private property) are ignored.

In one of our meetings with Nine Times, Raymond elaborated on his understanding of second lining as spirit work in a place where loved ones who have passed on continue to be present.

I don't second line for anybody uptown, or any other place except downtown in the Ninth Ward. There's too many guys who grew up down here that passed away- 
there's a lot of spirits around in this area, that I'd rather spend my talent, my feelings, and my heart to all the people down here that grew up with me and that's not on this earth here now. [conversation with authors, June 2005]

Here, Raymond seems to agree with geographer Steve Pile (2005) that haunted cities may be the only places where humans can live. Fellow club member Michael Simmons rejoins with his own personal acknowledgement that in joining Nine Times, he was also joining a spirit family:

I didn't know Mr. Louis, but I wished I had been a part of his life and had experiences with him. I know being a part of Nine Times, being a part of this family, I'm going to hear a lot about Mr. Louis because we talk about him a lot. Hopefully, when I get ready to come out the door, Mr. Louis will be right there with me, pushing me out that door. [conversation with authors, May 2005]

\section{RUMOR, REMOVAL, AND THE RIGHT OF RETURN: DIASPORIC MEMORIES}

On a Sunday afternoon in November of 2005, we are sitting down with Parker and Troy at Rachel's kitchen table. We are meeting to record their storm stories and catch up on life after Katrina. Most Nine Times members lost their homes in the flood. Many had been forced to relocate to other parts of the Ninth Ward, New Orleans East, and other downtown neighborhoods in New Orleans when Desire was torn down. The "New Desire," which was only partly constructed at the time of the storm, was destroyed by wind and water. Parker tells the story of using a pallet of wood that floated from the construction site to rescue his wife and a neighbor from their home in another part of the Ninth Ward. After evacuating to Baton Rouge and making sure other family members were situated in Atlanta, he has returned to work in New Orleans-living in a house with a number of other men whose families are still in exile.

Parker's phone rings. It is Charlene Mathews, the president of the Lady Nine Times, who is still in Houston, asking teasingly, "Y'all parading without me?" Today is their parade date-or as Troy puts it, "our day." On this day in November, Nine Times has been parading for the past eight years. Over two months after the flood, most of the club members as well as their family, friends, neighbors, and key supporters were still in exile. What is more significant, the vast majority of the Ninth Ward was a ghost town-empty of the necessary second liners who would come out to support the parade, feel proud of where they come from, and use the event as a relief from the multiple obstacles faced in daily life in a poor city.

Despite the obstacles of time and distance, Nine Times, other social and pleasure clubs, and residents who participate in the tradition through the second lines see parading as a route back to the city and to each other. In the first months after the storm, there were a number of parades organized in Baton Rouge and Houston. At these events, second liners used their cell phones to call friends and family scattered around the country to let them listen to the brass band music that defined Sunday afternoons in New Orleans for so many years.
Nine Times members have been networking with other clubs to continue parading in New Orleans. They have also decided to work with the Neighborhood Story Project on a book of their own. The majority of the members have returned to the city to take advantage of the reconstruction work, although most of their families are still in exile. Members meet once a week for writing workshops with the goal of having their book release party in conjunction with their annual parade in November of 2006. As city officials, planners, and developers write new plans for the city, Nine Times are writing their own stories of the Ninth Ward. In their written pieces, members reflect on their struggles to begin a second-line club in the Ninth Ward, and how the parade has served as a way of reuniting residents of the Desire after the development was torn down. It remains to be seen whether the Nine Times Social and Pleasure Club will physically be based out of the Ninth Ward again. It is possible to imagine the club functioning as a hub in a translocal network, organizing intermittent face-to-face gatherings and public events for their dispersed friends, relatives, and former neighbors. However, their commitment "never to forget where you came from" will still lead them back to streets called Higgins, Pleasure, Abundance, and Desire. They envision their next parade as a call back home-if only for an afternoon, former residents will be able to walk and dance through the streets embedded with their memories of the city.

On January 15, 2006, a coalition of over 30 social and pleasure clubs came together to participate in a parade to reclaim the streets of the city after four months of postKatrina diaspora. Thousands of displaced New Orleanians drove or flew in from Baton Rouge, Houston, Dallas, and Atlanta (and some from as far away as San Francisco, New York, and Portland) to participate in the parade; to check on their homes, neighborhoods, friends, and family; and assess the situation in the city. For some, it was their first time back in the city since the storm. The All-Star Second Line, as it was billed on the route sheet, drew over 8,000 people, filling several city blocks and capturing the imagination of photographers, journalists, videographers, and writers. Nine Times participated in force (see Figure 4).

Yet, as we write these lines, the future of the second-line tradition is very much in question, the demographic shift in the city initiated by the storm and flood and enforced through evacuations and Federal Emergency Management Agency (FEMA)-subsidized exile all continue to make the current New Orleans population whiter and wealthier than it was before the storm. Prompted by a series of shootings after the All-Star parade in January 2006, the New Orleans Police Department raised parade permit fees from approximately $\$ 1,600$ per club to $\$ 3,800 .{ }^{13}$ Organizers of the January parade protested that the police response effectively punishes the majority of law-abiding citizens who participate in second lines for the criminal actions of a few individuals. The clubs, organized as the Second Line Task Force, have initiated a series of meetings with police officials in the hope of reducing the fees, which they argue are prohibitive, forcing the majority of second-line organizations 


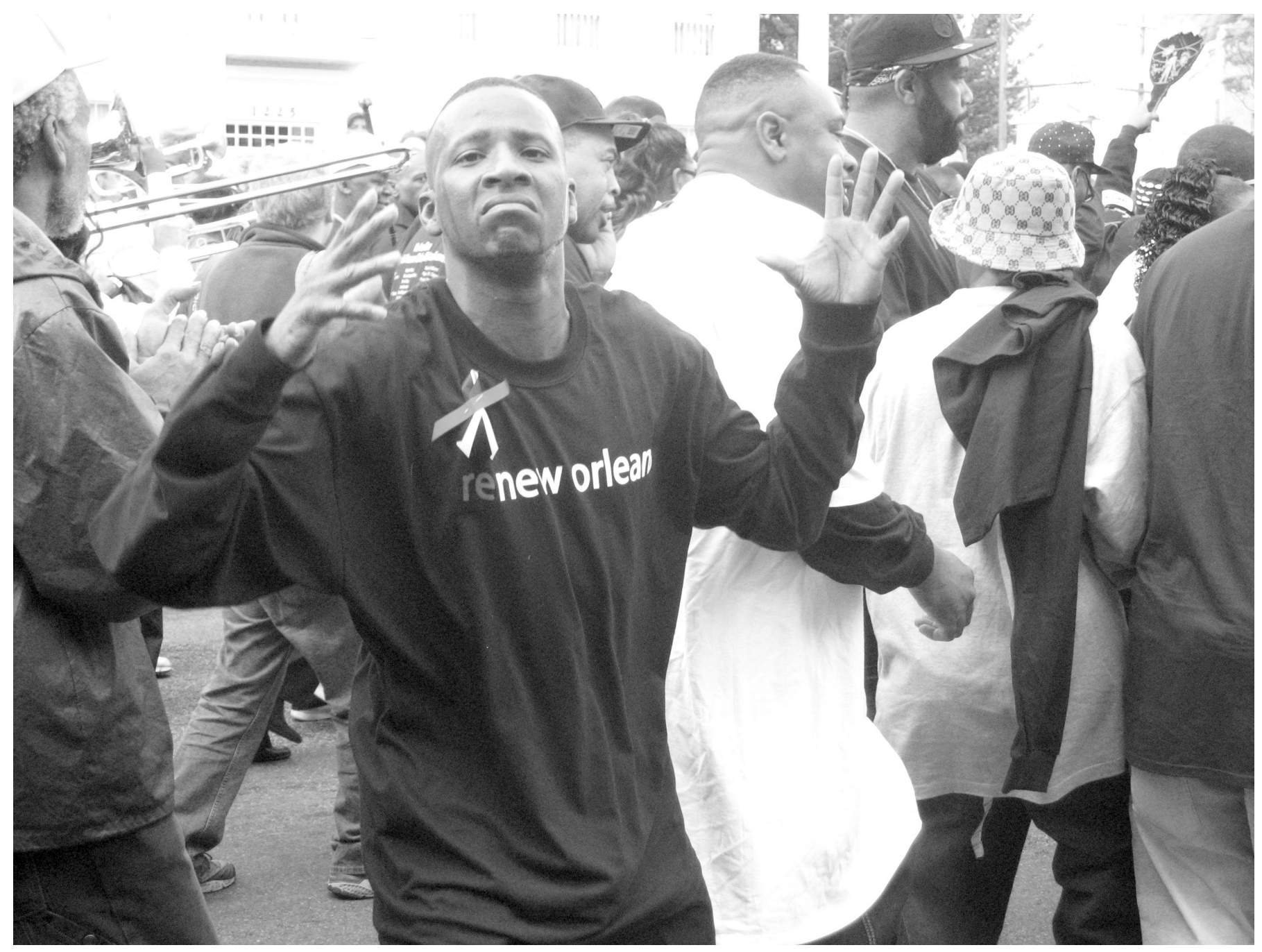

FIGURE 4. Gerald Platenburg, member of Nine Times, giving the Ninth Ward sign during the January 2006 All Star Parade. (Photograph by Rachel Breunlin)

to "retire from the streets." As this article goes to press, many brass band musicians still live in exile in Houston, Atlanta, Dallas, Austin, and such diverse locales as Phoenix and Boulder (Webster 2006). At one second-line parade, improvised chants took up the commentary on the seemingly blocked situation: "Fuck FEMA—-where's my FEMA?" While numerous businesses are unable to reopen or to resume full operations because of labor shortages, workers and their families are still unable to return because of evictions, halted home repairs, and absent or unusable FEMA trailers.

Among the many factors shaping New Orleanians' decisions-about whether and how to return or leave the city-is the complex web of rumor, news, and critical political and religious discourse about the meaning of the hurricane and its aftermath. For the men in the club whose partners and children are living in Houston and other locales in Louisiana, Texas, and Georgia, the decision about whether and how to reunite their families continues to be critical as most public schools in New Orleans remain closed. Most Nine Times members, like many New Orleani- ans, point discursively to a Biblical understanding of destiny and the necessity of accepting God's will and acknowledging one's blessings in the midst of personal hardship and social suffering. A powerful work ethic linked to notions of personal responsibility and self-help along with an antiracist ethic that refuses to lay blame for their woes on any particular social group are often associated with this Christian discourse of acceptance. Yet in the larger social world of black New Orleans, conspiracy theories abound.

The notion that the Ninth Ward's industrial canal levee was exploded intentionally, for example, is by no means a rare belief in New Orleans and exile communities, particularly among African Americans. ${ }^{14}$ Going beyond the anthropological insight that widely circulating rumors become social facts, it is worth considering how collective memory shapes political discourse in the African American communities of New Orleans.

Rumors circulating among exile communities, in evacuee settlements, and among those returning to the city to live and work attribute the current policies to an intentional 
effort on the part of white elites to reclaim New Orleans. What had for decades been a majority black city with a strong Democratic voting history (an island in the Republican south) would now possibly be reclaimed by those interests that had lost control of city hall with the 1978 election of the first black mayor of New Orleans, Ernest "Dutch" Morial. Glen Ford and Peter Gamble explain,

The commission's slogan, "Bring New Orleans Back," is a euphemism for bringing the city "back" to the days before Black rule by erecting multiple barriers to the return of Black residents. [Ford and Gamble 2006]

This rumor, perhaps best conceptualized as a working hypothesis, gained momentum when the Wall Street Journal published an inflammatory article on the perspectives of New Orleans elites planning the future of the city in an exclusive Dallas meeting with Mayor Ray Nagin (Cooper 2005). James Reiss, a member of the Dallas group and of the mayor's administration as chairman of the Regional Transit Authority, is prominently quoted in the article:

\begin{abstract}
The power elite of New Orleans ... insist the remade city won't simply restore the old order. New Orleans before the flood was burdened by a teeming underclass, substandard schools and a high crime rate.... The new city must be very different, Mr. Reiss [a member of Mayor Nagin's administration] says, with better services and fewer poor people. "Those who want to see this city rebuilt want to see it done in a completely different way: demographically, geographically, and politically," he says. "I'm not just speaking for myself here. The way we've been living is not going to happen again, or we're out." [Cooper 2005]
\end{abstract}

Within a very specific black-centered political discourse, a public sphere of conspiracy theories emerged after the flood. At the same time, an assertive civil rights language was being deployed by groups such as Acorn and the People's Hurricane Relief Fund and by black-owned media including electronic journals, such as the Black Commentator, and print media, such as the Tribune and the Louisiana Weekly. "It is not too early to say people have a right of return," wrote Black Commentator in a widely circulated electronic publication in September of 2005. Pointing to criminal neglect of levees by the U.S. Army Corps of Engineers-a federal agency-numerous civil rights groups, including Black Commentator writer Glen Ford, argued for a federal responsibility to assist those wishing to return to do so.

\begin{abstract}
Displacement based on race is a form of genocide, as recognized under the Geneva Conventions. Destruction of a people's culture, by official action or depraved inaction, is an offense against humanity, under international law. New Orleansthe whole city, and its people-is an indispensable component of African American culture and history. It is clear that the displaced people of New Orleans are being outsourced.... They are citizens of the United States, which is obligated to right the wrongs of the Bush regime, and its unnatural disaster. [Ford 2005, emphasis added]
\end{abstract}

Although this trenchant language is rarely seen or heard in mainstream media, it represents a significant critical discourse circulating by word of mouth via personal con- versations, cell phone networks, and Internet e-mail lists. The racialized effects of the storm are also documented by Brown University sociologist John R. Logan in a widely circulated study, "The Impact of Katrina: Race and Class in Storm-Damaged Neighborhoods." Logan writes in his final report that:

If the future city were limited to the population previously living in zones undamaged by Katrina it would risk losing about $50 \%$ of its white residents but more than $80 \%$ of its black population. This is why the continuing question about the hurricane is this: whose city will be rebuilt? [Logan 2006:16]

This analysis presents a worst-case scenario; many black and white residents have been returning to their flooded neighborhoods to rebuild. ${ }^{15}$ However, critical empirical work, such as Logan's, along with alternative media and the informal rumor networks provide an important counterdiscourse to the dominant liberal conversation on rebuilding, which emphasizes the need to use public funds to assist property owners and real estate developers while ignoring the concerns and contingencies of renters. This discourse has turned into reality as HANO and HUD announce their plans to "redevelop" public housing.

The assertion that the flooding, exile, and subsequent political economy of reconstruction may have racialized effects is a highly charged contention partly because the confluence of race and class in a preeminently U.S. city remains a taboo topic for many white New Orleanians. The refusal to acknowledge a larger history of displacement or to enter into a discussion of how the levee breech in the Ninth Ward and the lower Parishes was, in large part, the result of decades of privileging the shipping and oil and gas industry over working-class black and white residential communities is disingenuous and only adds more suspicion to the rumor networks. In the discussions around rebuilding, one point that most New Orleanians can agree on is that these gaps in experience and perspective have caused tremendous tension.

\section{CONCLUSION}

David Harvey writes in Spaces of Hope that "we know a great deal about what divides people but nowhere near enough about what we have in common. ... The insurgent architect has a role to play in defining commonalities as well as registering differences" (Harvey 2000:245). Social clubs like Nine Times may not be the insurgent architects Harvey had in mind, yet they are surely key players in the current reconstruction of the Desire and the Ninth Ward. If city planners, government officials, and developers would consider the routes that social and pleasure clubs weave throughout the city, they would discover a subaltern map-rich with physical and cultural data-that could be used to inform their own reports and recommendations. Regardless of whether top-down policy makers make a real commitment to understand the place attachments of working-class people in the city, New Orleans second-line networks have already 
begun recreating their communities. Among spirit families forged in response to structural violence-indeed, as in all African diaspora communities intimately familiar with displacement-reconnecting in the face of large and small disasters is nothing new. Through their participation in networks of public performance, New Orleanians have experienced the rupture and the reconstitution of complex social networks since the city began. Thus, as Abdou Maliq Simone puts it:

An experience of regularity capable of anchoring the livelihoods of residents and their transactions with one another is consolidated precisely because the outcomes of residents' reciprocal efforts are radically open, flexible, and provisional. [Simone 2004:408]

The regularity anchoring the experiences of displaced New Orleanians comes from the maintenance of networks, memory, and even rumor, all of which are sustained and disseminated through cell-phone conversation and new patterns of long-distance weekend and holiday travel marking birthdays, family reunions, and social club parades. The ultimate outcome of their open, flexible, and provisional living and working arrangements-their long-term effect on the social, cultural, economic, and political landscape of the city-are still unknown. Following Simone's suggestion that we take seriously the role of people as infrastructure-that is, as a "platform for reproducing life in the city" - we can expect that club members will bring all their intelligence, skill, and knowledge, their ways of being and doing-what some would call their "social and cultural capital" - and their heart to bear on the task ahead.

RACHel Breunlin The Neighborhood Story Project and Department of Anthropology, University of New Orleans, New Orleans, LA 70148

Helen A. Regis Department of Geography and Anthropology, Louisiana State University, Baton Rouge, LA 70803

\section{NOTES}

Acknowledgments. The authors wish to thank Waukesha Jackson and Evella "Ms. Coochie" Pierre for introducing us to their community in the Upper Ninth Ward. We are especially grateful to Nine Times members Troy Materre, Larry Moore, Jean Nelson, Raphael Parker, Gerald Platenburg, Michael Simmons, Charlene Williams, Raymond Williams, and Corey Woods for sharing their experiences with us and providing ongoing help and feedback throughout the process of writing this article. Portions of this article were presented at the annual meetings of the American Anthropological Association (2005) and the Association of American Geographers (2004), and at the joint conference of the Canadian Anthropological Society, Society for the Anthropology of North America and the Universidad Autónoma de Yucatán in Mérida, México (2005). Florence Babb, Dan Etheridge, and John Hargreaves read earlier drafts of the article and provided helpful comments. We are especially grateful to Ben Blount, Anne Lovell, and the anonymous reviewers for American Anthropologist as well as to all of our readers for their engaged readings and helpful critiques of the manuscript.

1. Although the flooding and prolonged exile have affected many New Orleanians of different race, ethnic, and class locations, we are primarily concerned in this article with lower-income African
Americans. We use "African American" and "black" interchangeably.

2. In the late 1990s, ten percent of the city's residents lived in public housing. The private-sector housing market was also in trouble because of the decay and abandonment of numerous buildings. According to Coleman Warner (1999; see also Lewis 2003:136), during the 1990 s there were 37,000 vacant housing units in the city, many of them blighted properties.

3 . There are a number of social and cultural organizations in black working-class social settings in New Orleans (including churches, Masonic organizations, carnival clubs, social clubs, and Mardi Gras Indian groups) that provide avenues for individual and group expression. People may participate in several of them simultaneously or at different moments in their lives. People often move between masking in the Mardi Gras Indian tradition and parading with social and pleasure clubs. The "Indians," or "Black Indians," as they are called in New Orleans, honor their Native American and African ancestors who sought freedom in Maroon communities on the margins of slave society.

4. Lakeview is almost exclusively white and Gentilly is a mixed neighborhood with significant black middle class. Pontchartrain Park was developed after World War II as a black middle- and uppermiddle-class subdivision (Thompkins 2005).

5 . These are paraphrased from the authors' field notes (September 2005).

6. The descendants of Italian, Sicilian, German, Polish, and Irish immigrants assimilated into whiteness, whereas many descendants of migrants from the sugar plantations and the interior South remained (or became) black as Jim Crow policies solidified.

7. Pierce Lewis writes:

Beginning in 1960, white flight shifted into high gear. White population plummeted, at the same time that black population continued to increase. By about 1974, for the first time since 1830, the number of blacks in New Orleans exceeded that of whites. By 2000, blacks outnumbered whites by a ratio of well over 2 to 1 . Throughout this period, the rate of white flight was such that the city's white population dropped from about 400,000 to fewer than 140,000 .... New Orleans had been converted from a white city with black enclaves to a black city with white enclaves. [Lewis 2003:177, see figure 65]

\section{According to Lewis:}

The fragmented black ghettos of old time New Orleans were getting bigger and bigger and beginning to merge into "superghettos," unlike anything the city had seen before. With the racial switchover, it was whites who now found themselves set apart from the majority of the city's population. One could hardly describe white districts as ghettos in the traditional usage of the word; golden ghettos would be more accurate. ... All in all, New Orleans was more segregated than it had ever been, and the inequities between rich and poor were as extreme as any time since the legal end of slavery. In the meantime, a good share of New Orleans's middle-class population had decamped. [Lewis 2003:127-128]

9. Criticism often focused on access to essential city services. As one former New Orleans resident recalls, "I remember Desire being geographically segregated because the canal was on one side, the railroad tracks on another and there was only one way out of the projects. This caused problems, for example, when ambulances had to get in and out quickly" (personal communication, May 3, 2006).

10. This quote is a composite, paraphrased, from statements by architects, urbanists, preservationists, residents, and community activists based on our experience of living in New Orleans for the past 
nine months and participating in numerous conversations around rebuilding.

11. One member of Nine Times, Gerard Platenburg, even performed at the famous Apollo Theater in Harlem during the DJ and break-dance movement of the early 1980s.

12. Desire was demolished in stages. Units were torn down in 1996, 1998, and 2001.

13. New Orleans Jazz and Heritage Festival Producer Quint Davis paid for some recent social club parades through the Norman Dixon, Senior Memorial Foundation, to ensure that no parade be cancelled. This was reported to a meeting of the Second Line Task Force on January 19, 2006. In May 2006, the American Civil Liberties Union announced it would file a lawsuit against the New Orleans Police Department if it did not lower the fees. "Unreasonable and excessive fees," they argue, are "infringing on [club members'] first amendment rights" (Eggler 2006; see also Troeh 2006).

14. This generalization is based on dozens of conversations with New Orleanians of diverse educational and socioeconomic backgrounds. This point was also made by Gregory Button during a presentation at the 2005 meetings of the American Anthropological Association, special panel on Hurricane Katrina. Of course, many black New Orleanians explicitly disavow this theory, while pointing to structural factors shaping opportunities for people of color.

15. A more recent Brookings Institute report suggests that those returning to New Orleans are likely to find work, while others face sharply rising unemployment rates:

The unemployment rate of those that remain displaced jumped to nearly 35 percent in March 2006, a 54 percent increase from the preceding month. Displaced families continue to wrestle with substantial obstacles to finding jobs and restarting their lives now nearly eight months since Katrina made landfall. Meanwhile, those who have returned to New Orleans are likely to be employed, with their overall unemployment rates better than pre-Katrina. [Katz and Fellowes 2006:5]

This confirms what we are observing among friends and neighbors. For many, getting back home, being able to tap into personal networks, and the huge need for labor right now seems to make people more stable again.

\section{REFERENCES CITED}

Altman, Irwin, and Setha M. Low, eds.

1992 Place Attachment (Human Behavior and Environment). New York: Plenum Press.

Ashe, Bertram D.

1999 On the Jazz Musician's Love/Hate Relationship with the Audience. In Signifiyin(g), Sanctifyin' and Slam Dunking: A Reader in African American Expressive Culture. Gena Dagel Caponi, ed. Pp. 277-289. Amherst: University of Massachusetts Press.

Atler, Jonathon

2005 The Other America: An Enduring Shame. Poverty, Race, and Katrina: Lessons of a National Shame. Newsweek, September 19:42-48.

Baker, Houston

1993 Black Studies, Rap, and the Academy. Chicago: University of Chicago Press.

Basso, Keith

1996 Wisdom Sits in Places: Landscape and Language among the Western Apache. Albuquerque: University of New Mexico Press

Bishara, Amahl

2003 House and Homeland: Examining Sentiments about Claims to Jerusalem and Its Houses. Social Text 21(2):141162.

Blomley, Nicholas

2002 Mud for the Land. Public Culture 14(3):557-582.
2003 Unsettling the City: Urban Land and Politics of Property. New York: Taylor and Francis.

Breunlin, Rachel

2004a "Papa Joe" Glasper and Joe's Cozy Corner: Downtown, Displacement, and the Creation of Community. M.A. thesis, Department of Anthropology, University of New Orleans.

2004b Space Swapping: Urban Renewal and Public Housing. Electronic document, http://www.endsound.com/nopf/ socialcomments/spaceswapping.htm, accessed March 3.

2005 The Legacy of the Free Southern Theater in New Orleans: Interviews with Karen Kaia-Rivers and Chakua Cha Jua. Electronic document, http://www.nathanielturner.com/ legacyfreesouttheater.htm, accessed October 31.

Burns, Mick

2006 Keeping the Beat on the Street: The New Orleans Brass Band Renaissance. Baton Rouge: Louisiana State University.

Campanella, Richard

2006a Geographical History and Future of New Orleans. In Reinhabiting New Orleans. Final Report of the Reinhabiting Nola Workshop. Electronic document, http://www.kerrn.org/ pdf/ReinhabitNOLA.pdf, accessed January 26.

2006b Geographies of New Orleans: Urban Fabrics before the Storm. Lafayette: Center for Louisiana Studies.

Campanella, Richard, and Marina Campanella

1999 New Orleans: Then and Now. Gretna, LA: Pelican Publishing.

City Planning and Zoning Commission

1952 Report and Recommendation for Selection of Low-Rent Housing Project Sites for Negro Occupancy. City Archives. Main Branch of New Orleans Public Library, New Orleans, LA.

Colten, Craig E.

2005 Unnatural Metropolis: Wresting New Orleans from Nature. Baton Rouge: Louisiana State University Press.

Cooper, Christopher

2005 Old-Line Families Escape Worst of Flood and Plot Future. Wall Street Journal: September 8. Electronic document, http:// www.commondreams.org/headlines05/0908-09.htm, accessed July 4, 2006.

Crutcher, Michael

2001 Protecting Place in African-American Neighborhoods: Urban Public Space, Privatization, and Protest in Louis Armstrong Park and the Tremé, New Orleans. Ph.D. dissertation, Department of Geography and Anthropology, Louisiana State University.

DeFilippis, James, and Peter North

2004 The Emancipatory Community: Place, Action, and Collective Politics in Cities. In The Emancipatory City? Paradoxes and Possibilities. Loretta Lees, ed. Pp. 72-88. London: Sage.

Dent, Thomas

1982 Blue Lights and River Songs. Detroit: Lotus.

Dent, Thomas C., Richard Schechner, and Gilbert Moses

1969 Free Southern Theater by The Free Southern Theater. Indianapolis: Bobs- Merrill.

Displaced

2002 An Exhibition and Symposium on the Fate of Displaced Public Housing Residents. New Orleans: Barrister's Gallery.

Domínguez, Virginia

1986 White by Definition: Social Classification in Creole Louisiana. New Brunswick, NJ: Rutgers University Press.

Eaton, Leslie

2006 Hurricane Aid Flowing Directly to Homeowners. New York Times, July 17:A1.

Eckstein, Barbara

2006 Sustaining New Orleans: Literature, Local Memory, and the Fate of the City. New York: Routledge

Eckstein, Barbara, and James A. Throgmorton, eds.

2003 Story and Sustainability: Planning, Practice, and Possibility for American Cities. Cambridge, MA: MIT Press.

Economist

2005 The Shaming of America. Economist, September 10:11, 26-29.

Eggler, Bruce

2006 Second-Line Fees Are Too High, ACLU Says; Police Chief 
Is Urged to Lower Escort Price. Times-Picayune, May 17, 2007. Electronic document, http://nola.com, accessed May 17.

Fields, Willard

2004 Urban Landscape Change in New Orleans, LA: The Case of the Lost Neighborhood of Louis Armstrong. Ph.D. dissertation, College of Urban and Public Affairs, University of New Orleans.

Filosa, Gwen

2005 I'm Tired of Being Forced out of My City. Times-Picayune, November 6: 1. Electronic document, http://www.web.lexisnexus.com, accessed November 27.

2006 Four N.O. Housing Developments Will Be Demolished; But 1,000 Other Units to Reopen by August. Times-Picayune, June 15: 1 .

Ford, Glen

2005 New Orleans Population Has the Right of Return. Radio BC Commentary. Black Commentator. September 8, 2005. Electronic document, http://www.blackcommentor.com, accessed September 20.

Ford, Glen, and Peter Gamble

2006 Fighting the Theft of New Orleans: The Rhythm of Resistance. Black Commentator 167, January 19, 2006. Electronic document, http://www.blackcommentator.com, accessed January 23.

Gottdiener, M.

1985 The Social Production of Urban Space. Austin: University of Texas Press.

Greater New Orleans Data Center

2005 Desire Area Neighborhood Snapshot. Electronic document, http://www.gnocdc.org/orleans/7/15/snapshot.html, accessed October 31.

Greenbaum, Susan

2002 Report from the Field: Social Capital and Deconcentration: Theoretical and Policy Paradoxes of the HOPE VI Program. North American Dialogue (September) 5(1):9-13.

Gupta, Akhil, and James Ferguson

1999 Beyond "Culture": Space, Identity, and the Politics of Difference. In Culture, Power, Place: Explorations in Critical Anthropology. Akhil Gupta and James Ferguson, eds. Pp. 1-32. Durham, NC: Duke University Press.

Harvey, David

2000 Spaces of Hope. Berkeley: University of California Press.

Haymes, Stephen Nathan

1995 Race, Culture, and the City: A Pedagogy for Black Urban Struggle. New York: State University of New York Press.

Hirsch, Arnold R.

2000 Searching for a "Sound Negro Policy": A Racial Agenda for the Housing Acts of 1949 and 1954. Housing Policy Debate 11(2):393-441.

1998[1983] Making the Second Ghetto: Race and Housing in Chicago, 1940-1960. Chicago: University of Chicago Press.

Hirsch, Arnold, and Joseph Logsdon

1992 Introduction: Franco-Africans and African-Americans. In Creole New Orleans: Race and Americanization. Arnold R. Hirsch and Joseph Logsdon, eds. Pp. 189-200. Baton Rouge: Louisiana State University.

Holston, James

1999 The Modernist City and the Death of the Street. In Theorizing the City: The New Urban Anthropology Reader. Setha M. Low, ed. Pp. 245-276. New Brunswick, NJ: Rutgers University Press.

Jackson, John L., Jr.

2001 Harlemworld: Doing Race and Class in Contemporary Black America. Chicago: University of Chicago Press.

Jackson, Kenneth

1985 Crabgrass Frontier: The Suburbanization of the United States. Oxford: Oxford University Press.

Jackson, Waukesha

2005 What Would the World Be Without Women? Stories from the Ninth Ward. New Orleans: Neighborhood Story Project and Soft Skull Press-Red Rattle Books.

Johnson, Jerah

1995 New Orleans's Congo Square. New Orleans: Louisiana Landmarks Society.
Joseph, Miranda

2002 Against the Romance of Community. Minneapolis: University of Minnesota Press.

Katz, Bruce, and Matt Fellowes, eds.

2006 Katrina Index: Tracking Variables of Post-Katrina Reconstruction. Washington, DC: Brookings Institution Metropolitan Policy Program. Electronic document, http://www. brookings.edu/metro/pubs/200512_katrinaindex.htm, accessed May 9.

Kelman, Ari

2003 A River and Its City: The Nature of Landscape in New Orleans. Berkeley: University of California Press.

Lewis, Peirce

2003[1973] New Orleans: The Making of an Urban Landscape. Santa Fe: Center for American Places.

Logan, John R.

2006 The Impact of Katrina: Race and Class in Storm-Damaged Neighborhoods. Electronic document, http://www.gnodc.org, accessed May 9.

Low, Setha M.

1999 Spatializing Culture: The Social Production and Social Construction of Public Space in Costa Rica. In Theorizing the City: The New Urban Anthropology Reader. Setha M. Low, ed. Pp. 111-137. New Brunswick, NJ: Rutgers University Press.

2003 Behind the Gates: Life, Security, and the Pursuit of Happiness in Fortress America. New York: Routledge.

Low, Setha M., and Denise Lawrence-Zuniga, eds.

2003 The Anthropology of Space and Place: Locating Culture. New York: Blackwell.

Neighborhood Story Project

2006 Neighborhood Story Project. Electronic document, www.neighborhoodstoryproject.org, accessed January 15.

Newman, Katherine

2000 No Shame in My Game: The Working Poor in the InnerCity. New York: Alfred A. Knopf and the Russell Sage Foundation.

Osbey, Brenda Marie

1997 All Saints: New and Selected Poems. Baton Rouge: Louisiana State Press.

Pile, Steve

2005 Real Cities: Modernity, Space, and the Phantasmagorias of City Life. London: Sage.

Regis, Helen A.

1999 Second Lines, Minstrelsy, and the Contested Landscape of New Orleans Afro-Creole Festivals. Cultural Anthropology $14(4): 472-504$.

2001 Blackness and the Politics of Memory in the New Orleans Second Line. American Ethnologist 28(4):752-777.

2005 Desire, Hope VI, and Spatial Transformations in New Orleans. Paper presented at the joint conference of the Society for the Anthropology of North America, the Canadian Society for Cultural Anthropology, and Universidad Autónoma de Yucatán, "Translocalidad: Diálogos sobre la cultura y el cambio en el Siglo XXI," Merida, Mexico, May 4.

Roseman, Marina

1998 Singers of the Landscape: Song, History, and Property Rights in the Malaysian Rain Forest. American Anthropologist 100(1):106-121.

Rutheiser, Charles

1999 Making Place in the Nonplace Urban Realm: Notes on the Revitalization of Downtown Atlanta. In Theorizing the City: The New Urban Anthropology Reader. Setha M. Low, ed. Pp. 317-341. New Brunswick, NJ: Rutgers University Press.

Roach, Joseph

1996 City of the Dead: Circum-Atlantic Performance. New York: Columbia University Press.

Saloy, Mona Lisa

2005 Red Beans and Ricely Yours. Kirksville, MO: Truman State University Press.

Samuel, Daniel Roberts

2000 Remembering North Claiborne: Community and Place in Downtown New Orleans. M.A. thesis, College of Urban and Public Affairs, University of New Orleans.

Sasser, Bill

2006 "This Is Our Home." Tenants of Public Housing across 
New Orleans Feel Frozen out and Unwelcome-at the Hands of Their Landlord, HANO. Gambit Weekly, April 11. Electronic document, http://gambitweekly.com, accessed April 15.

Scott, James

1998 Seeing Like a State: How Certain Schemes to Improve the Human Condition Have Failed. New Haven, CT: Yale University Press.

Simone, Abdou Maliq

2004 People as Infrastructure: Intersecting Fragments in Johannesburg. Public Culture 16(3):407-429.

Smith, Neil

1996 The New Urban Frontier: Gentrification and the Revanchist City. New York: Routledge.

Sorkin, Michael, ed.

1992 Variations on a Theme Park: The New American City and the End of Public Space. New York: Hill and Wang.

Soul Rebels

1992 Let Your Mind Be Free. New Orleans: Mardi Gras Records.

Stack, Carol

1974 All Our Kin. New York: Harper and Row.

1996 Call to Home: African Americans Reclaim the Rural South. New York: Basic Books.

1998 Holding Hands: An American Struggle for Community. Cultural Diversity in the U.S. South: Anthropological Contributions to a Region in Transition. C. E. Hill and P. D. Beaver, eds. Pp. 93-103. Athens: University of Georgia.

Thompkins, Gwendolyn

2005 Return to New Orleans: Pontchartrain Park. Weekend Edition, December 3. Electronic document, http://www.npr.org, accessed December 12.

Times-Picayune

1979 Desire Residents Sue HUD. Section 1, Times-Picayune, October 17: 2 .

Troeh, Eve

2006 Second-Line Fees. Gambit Weekly, June 27, 2006. Electronic document, http://www.bestofneworleans.com/ dispatch/current/news_feat2.php, accessed July 2 .

UN Office of High Commissioner for Human Rights

2006 Guiding Principles on Internal Displacement. Electronic document, http://www.unhchr.ch/html/menu2/7/b/ principles.htm, accessed July 2.

Venkatesh, Sudhir

2000 American Project: The Rise and Fall of a Modern Ghetto. Cambridge, MA: Harvard University Press.
Verdery, Katherine

1998 Transnationalism, Nationalism, Citizenship, and Property: Eastern Europe Since 1989. American Ethnologist 25(2):291306.

Walker, Rob

2005 Letters from New Orleans. New Orleans: Garrett County Press.

Walsh, Bill

2006 White House against Baker Buyout: Bush Point Man Says Block Grants Enough. Times-Picayune, January 25:1. Electronic document, http://www.nola.com, accessed April 20.

Ward, Martha

2004 Voodoo Queen: The Spirited Lives of Marie Laveau. Jackson, MS: University Press of Mississippi.

Ward, Martha C.

1986 Poor Women, Powerful Men: America's Great Experiment in Family Planning. Boulder, CO: Westview Press.

1995 Early Childbearing: What Is the Problem and Who Owns It? In Conceiving the New World Order: The Global Politics of Reproduction. Faye Ginsburg and Rayna Rapp, eds. Pp. 140158. Berkeley: University of California Press.

Warner, Coleman

1999 A Blight on the City. Times-Picayune, May 9: A1.

Webster, Richard A.

2006 New Orleans Jazz Fest Marks Homecoming for Some Area Bands. New Orleans City Business, April 14. Electronic document, http://neworleanscitybusiness.com, accessed May 20.

White, Brice

2004 Interviews with New Orleans Black Panthers. Electronic document, http://www.endsound.com/nopf/socialcomments/ desire.htm, accessed March 3.

Williams, Brett

1988 Upscaling Downtown. Ithaca, NY: Cornell.

ya Salaam, Kalamu

1988 Notes from a Banana Republic. Dialogue 78 (OctoberNovember):11-17.

2000 Spirit Family of the Streets. New Orleans Tribune 16(2):2829.

Zhang, Li

2001 Migration and Privatization of Space and Power in Late Socialist China. American Ethnologist 28(1):179-205.

2002 Spatiality and Urban Citizenship in Late Socialist China. Public Culture 14(2):311-334.

Zukin, Sharon

1991 Landscapes of Power: From Detroit to Disney World. Berkeley: University of California Press. 